\title{
A multi-factor model developed on residents' opinions for the classification of urban residential areas
}

\author{
PÉTER GYENIZSE ${ }^{1}$, ANDRÁS TRÓCSÁNYI ${ }^{1}$, GÁBOR PIRISI ${ }^{1}$, \\ ZITA BOGNÁR ${ }^{2}$, SZABOLCS CZIGÁNY ${ }^{1}$
}

\begin{abstract}
${ }^{1}$ University of Pécs, Faculty of Sciences, Institute of Geography, Hungary; e-mail: gyenizse@ gamma.ttk.pte.hu, troand@gamma.ttk.pte.hu, pirisig@gmail.com, sczigany@gamma.ttk.pte.hu ${ }^{2}$ University of Pécs, Faculty of Sciences, Doctoral School of Earth Sciences, Hungary; e-mail: bognarzi@gamma.ttk.pte.hu
\end{abstract}

ABSTRACT The process of social differentiation in post-communist states has had a clear impact on the status of neighbourhoods. Municipalities have tried to handle the problem, but planning in Hungary is still based on shallow analyses. This paper presents a method for examining and quantifying prevailing factors of residential areas, also being able of a spatial comparison. It detects problematic issues and locations and assists in the formulation of solutions. The model city for the presented study was Szeged, located in southeastern Hungary. Szeged is the economic center of the region and it was an ideal urban area for the evaluation of housing needs and for the mapping of various objects and social services. A field-collected qualitative database was processed using the Idrisi Selva GIS program, resulting in a classifying map of investigated areas. We have localized the properties of the lowest score and also determined the major issues responsible for low scores by analysing the spatial data of 27 GIS layers. The model can be used to detect the reasons causing differences in the perception of neighbourhoods, while it may serve as a tool for decision makers.

KEY WORDS urban residential areas - apartment blocks - segregation - multi-factor rating Szeged - Idrisi - GIS

GYENIZSE, P., TRÓCSÁNYI, A., PIRISI, G., BOGNÁR, Z., CZIGÁNY, S. (2016): A multi-factor model developed on residents' opinions for the classification of urban residential areas. Geografie, $121,1,1-31$.

Received February 2015, accepted November 2015.

(C) Česká geografická společnost, z. s., 2016 


\section{Introduction}

The general and individual characteristics of post-socialist urban transition has most often been explored and analysed (Kovács 1999; Sailer-Fliege 1999; Stanilov 2007a; Andrusz, Harloe, Szelényi 2008; Sýkora, Bouzarovski 2012; Hirt 2013) for the context of local processes in capitals, and for regional processes in their relation to other major cities (Kiss 2004; Gentile 2004; Kotus 2006; Cavrić, Toplek, Šiljeg 2008). The vast majority of these studies consider the processes in urban residential areas as central factors in the transition. The simultaneous development of the real estate market, and the differentiation of society, fundamentally transformed the spatial structure of cities, with the main leitmotif of segregation or polarization (Sýkora 1999; Gentile 2003; Ruoppila, Kährik 2003; Marcińczak, Gentile, Stępniak 2013). Although regional differences and peculiarities of individual municipalities within the housing market have a significant impact on local processes, in general it is concluded that transition was greatly influenced by the processes following the highly typical absence of market-based management of planned economic features in the transformation of housing (Elekes 2008, Hirt, Stanilov 2007). Local elites of the transition have developed remaining prestigious residential areas of the interwar period according to their image, and created entirely new residential areas initially on the edges of cities and beyond, then, as a result of gentrification, also in central historical urban areas (Kovács 1998). The residential areas of the new middle-class were differentiated, some transformed into slums, while some could maintain their fair status and position (Kovács 2009). This very process of sharp polarisation was also typical of the building of emblematic residential apartment blocks, as part of the socialist urban development (Hirt 2013).

Urban transition often went astray during the crisis of urban planning in the 1990s, which can be referred to as the era of planning crisis (Stanilov 2007b). This resulted from an urban management lacking experience relevant to the changed driving forces behind the system, and judging neoliberal views in theory and practice as being the antithesis of the long-existing centralized planning system, and from the financial difficulties of the affected populations.

Long after the millennium the situation finally started to recover as a result of a new integrated strategic planning developed partly on the basis of the Leipzig Charter, and the impact of more active local governments (Tsenkova 2007). Still, strategic planning in Hungary remained fairly modest in terms of equipment and devices, relying on shallow background research and analyses. The complex issue of segregation and the expansion of brownfields, changing demographic trends and household structures made the question of residential areas become a problematic subject, which also requires (again) centralised intervention. However, local communities have not yet widely implemented procedures in their planning 
practice that apply GIS-based models to support the accomplishment of urban policy objectives.

Statistical and GIS tools provide a possibility for classifying certain individual settlements or settlement groups with multiple factors. The methods offered by these programs are excellent preparation tools for decision-makers of urban management. Their areas of application and spatial resolution are determined by the amount of data available, the quality, its accesibility, how up to date the data are etc. It is rarely possible to find large scale data in a city's statistics smaller than its districts, for they are generally considered as the basic units. These more detailed social-, city service-, transportation-, land-use-related measures allow for assessing residential environments in such units (Grekousis, Manetos, Photis 2013) and modeling future trends (Gaube, Remesch 2013).

Provided that more detailed spatial and statistical data are available, GIS programs can quantitatively analyse spatial change in urban residential land areas (Aljoufie et al. 2013). Using fuzzy logics also simplifies the method for localizing residential establishments (Svoray, Bar, Bannet 2005; Czigány et al. 2010; Ronczyk et al. 2012; Gbanie et al. 2013). GIS is considered an important tool in determining public transportation routes and cycling infrastructure (Zhou, Thill, Huang 2011; Rybarczyk, Wu 2010). Case and Hawthorne (2013) studied the low income districts of Atlanta, by focusing on the potential accessibility of social services. According to the authors, the crucial issue is not the presence of a given service, it is rather its accessibility for the local residents. The authors localized social services, including bus stops, railway stations, bus routes and the surrounding buffer zones. During their case study they consulted with the social service suppliers, leaders of civil organizations and directly with local residents. They also discussed the potential future locations of selected social services.

Multifactor analyses were carried out by Martínez (2000) in the southern districts of Rosario, where significant shortcomings were found in basic social services. Based on the criteria of the UN HABITAT, the author indirectly evaluated housing needs, which was later compared with the needs of the local residents. The author also assessed the accessibility of basic services and defined a maximum distance of 750 meters from a given service for mothers and elderly residents. Maps were created with multiple layers that contained the various social services and their buffer zones. Myint (2008) did not analyse the accessibility of services, but rather focused on the statistic-spatial analysis of the social economics on the example of the city of Norman. During his studies he calculated the spatial mean centres of the clusters of banks, fast-food restaurants, schools and churches (point clouds of the locations), measured the distance around these facilities, then with the help of the standard deviation ellipse he defined the spatial distribution of the point clouds. Finally, point distributions with the nearest neighbour analysis the author determined the spatial pattern of the point cloud. With the network 
K function method he defined whether the individual point clouds mutually impact each other. Nonetheless his study was entirely based on mathematical analyses, while residential needs were entirely neglected. Nevertheless, the results provide useful bases for the prediction of future urban sprawl.

Although focusing on a different topic, similar multifunctional methods were applied by Achillas et al. (2011). The authors's major objective was to identify the most significant environmental impacts in Thessaloniki, and to evaluate the potential solutions with the assistance of expert scientists. The most significant environmental issue was identified based on the residential feedback in the form of questionnaires and personal interviews. Local residents were already involved in early phase of the project planning by the urban planners. The individual solution alternatives were weighted based on selected criteria. Finally, the optimal solutions were ranked and the best solution was selected with the outranking method.

\subsection{Objective}

This paper is based on a case study and proposes a method built on a GIS model to map motivations behind choosing a place to reside, and through this, to create a complex classification of urban residential areas. As it is detailed later in this study, the proposed model integrates geographically determined "solid" factors with "soft" factors reflecting populations' choice of values. It rates residential areas based on the opinions of residents and experts, and shows, which areas residents find attractive or unappealing. As a result, this model can put urban structures into new perspectives, allowing for creating grounded strategies to develop urban living and related areas. The requirements for the finished model are to provide for independent quantitative analysis and spatial comparison of prevailing local factors, to enable determining problematic factors, and to facilitate solutions. We aimed to build such a model that also allows for examining individual buildings due to its high quality spatial resolution. We will also present examples of the model's application possibilities.

\subsection{Test site of the model: the city of Szeged}

Szeged is a city located in the south-eastern part of Hungary with a population of 161,837 (2013, Gazetteer of Hungary). Szeged is a regional centre of transportation, culture, education and industry (Fig. 1). The city is built on the floodplains of the rivers Tisza and Maros, and has been destroyed by the floods multiple times. Its landscape is characterised by mainly floodplains with minor differences in altitude 


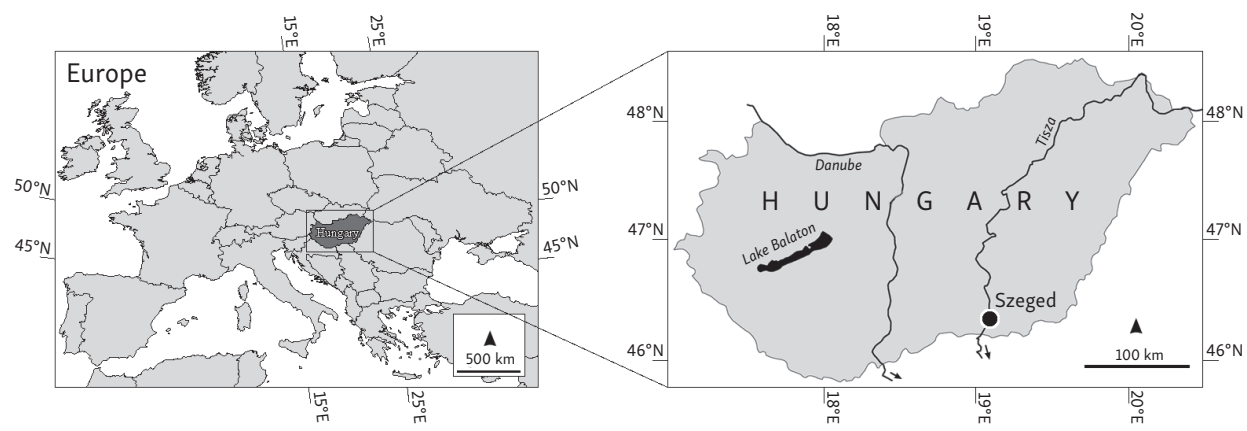

Fig. 1 - Geographical location of Szeged. Source: Gyenizse 2014.

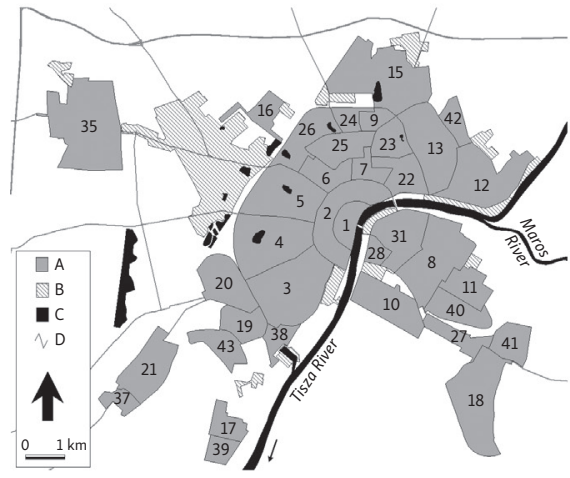

A

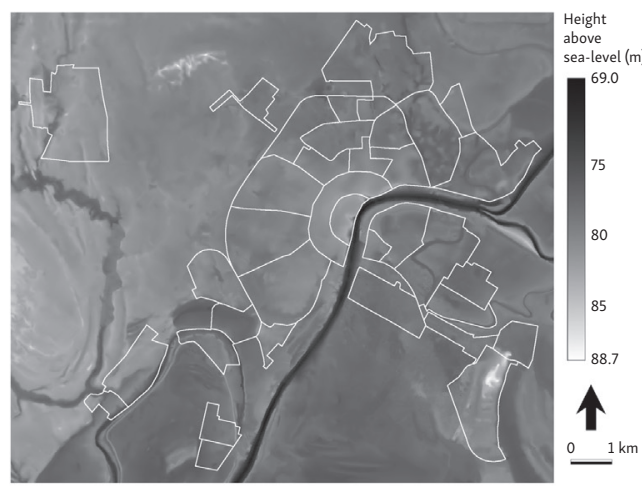

B

Fig. 2 - City zones and landscape of Szeged. A - residential areas, B - industrial and floodplain holiday home areas not included in the study, $C$ - rivers and lakes, D - roads

1 - Centre, 2 - Inner city, 3 - Lower city, 4 - Móraváros, 5 - Rókus-Móraváros, 6 - Rókus, 7 Ófelsőváros, 8 - Újszeged, 9 - Fodor-kert, 10 - Fűvészkert, 11 - Marostő, 12 - Tápé, 13 - Petőfitelep, 15 - Baktó, 16 - Béketelep, 17 - Gyálarét, 18 - Szőreg, 19 - Klebelsberg-telep, 20 - Kecskés-telep, 21 - Szentmihály, 22 - Upper city, 23 - Tarján, 24 - Makkosháza, 25 - Northern city, 26 - Újrókus, 27 - Újszőreg, 28 - Odessza, 31 - Villas, 35 - Kiskundorozsma, 37 - Bodomi residential gardening areas, 38 - Ballagitói residential gardening areas, 39 - Gyálaréti residential gardening areas, 40 Marostői residential gardening areas, 41 - Szőregi residential gardening areas, 42 - Tápéi residential gardening areas, 43 - Tompaszigeti residential gardening areas. Source: Gyenizse 2014.

(Fig. 2B). The core of the city was built on the highest areas of the floodplain: Upper City (Felsőváros), Centre (Belváros), and Lower City (Alsóváros). Szeged was destroyed many times by the wars of the Middle Ages and by natural disasters. Its current state reflects its structure built in 1879 when the city was rebuilt after a near total destruction by flood. This reconstruction involved the building of a new system of avenues and boulevards that still define the central urban morphology structure of the city (Gaál 1991, Bajmócy 2009). The town of Szeged 
was united with Újszeged, another town on the opposite side of the river Tisza, to become a single city in 1880. Later in the socialist era, a number of large-scale residential blocks (housing estates) were built in Szeged and surrounding villages (e.g. Gyálarét, Kiskundorozsma, Szőreg, Tápé) were officially attached to the city (Blazovich 2010). The regions analysed in this paper are shown in Figure 2A. Only those urban areas were examined, which are in direct connection with each other. We did not include remote small farms and smaller house clusters in our study. Due to the above detailed characteristics (flat plain, building uniformity) of the city, its spatial structuring represent one of the country's most homogeneous settlement models in which the prominent features of spatial distribution include systematic centre blocks bound by avenues and boulevards, as well as a decrease of built-up density by the increasing distance from the city centre.

\section{Methodology}

For residents, properties represent various values. In our model, we have determined relative spatial value differences. Attractive or negative features depend on the properties of the dwellings (e.g. building material), but they are also impacted by the characteristics of the neighborhood (vicinity of parks or industrial areas). Figure 3A illustrates the basic concepts of the evaluation system. Based on this polarized example, the apartments of district 1 are located closer to the undesired objects (e.g. industrial plant) and are found farther away from attractive areas (e.g. parks) than the family houses in district 2 . Furthermore, apartments in concrete blockhouses are less preferred dwellings than family houses built of bricks. Consequently, based on the physical properties and the distances from the adjacent infrastructural, traffic, educational and general services that dwellings in district 2 are more attractive than the apartment houses of district 1.

However, the model differentiates and ranks the apartments of similar properties in district 1 . Due to its better location, building " $a$ " is more attractive than buildings " $b$ " or " $c$ ", furthermore within the same blockhouse, apartments of staircase "b1" are better localized than those of in staircase "b2".

For the completion of the model, a raster-based model was used, as vectorbased models can only calculate distance along a pre-determined and pre-defined route (essentially Manhattan route). However, noise and fetor is transported by diffusion, and not along predefined routes. Residents often trespass in parks, abandoned areas, or cross and jaywalk streets and railroads where passing is unlawful. For vector-based applications, all trails, front and backyard entrances and gates need to be known. That would mean an unrealistically large database and mapping efforts with low return efficiency. These shortcomings can be tackled down with the raster-based approach, however distance calculations need to be corrected 


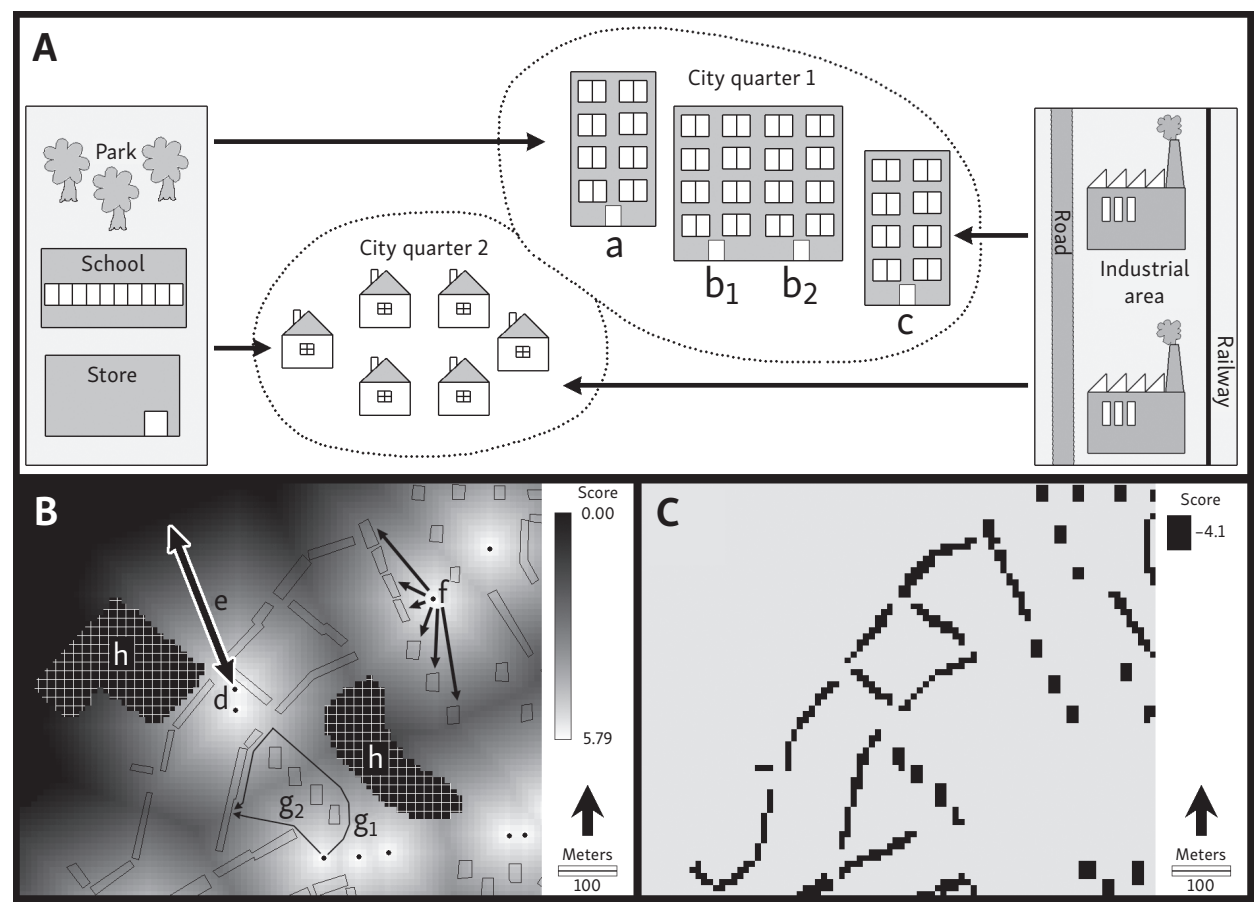

Fig. 3 - Based on the principle of the model, the value of the properties depends on the distances to adjacent services and the physical properties of the buildings. This was then visualized and modeled in rasterized GIS layers (see the text for further details). Source: Gyenizse 2015.

(Chapter 2.4) and appropriate pixel size need to be carefully chosen (Gyenizse, Elekes, Nagyváradi 2012). The distance measurement with raster-based models is more inaccurate, but its advantage is that it requires less input data, calculates faster and enables the application of GIS modules like the Over Times Series function of the Profile Module (Chapter 3.2).

On Figure 3B we presented an example on the decreasing preference of dwellings as a function of increasing distance from the objects of infrastructural importance. The impact of bus, trolley and tram stops ("d") for the value of properties is valid up to distance "e" in a gradually decreasing trend (Chapters 2.1 and 2.4). In other words, with increasing distance from the relevant stops, each pixel is assigned with a lower value, and beyond distance "e", the pixel receives no value. Consequently, the pixels of the properties will indicate the real value of the given dwelling, as properties in the proximity of the stops receive higher value, while obtain lower value if located at a greater distance ("f"). Routes "gl" and "g2" indicate the route planning problems of pedestrians. According to the vector-based program a pedestrian can reach home from the bus stop in the shortest distance via route "gl". Reality often differs from the idealistic route "g2", as pedestrians may 


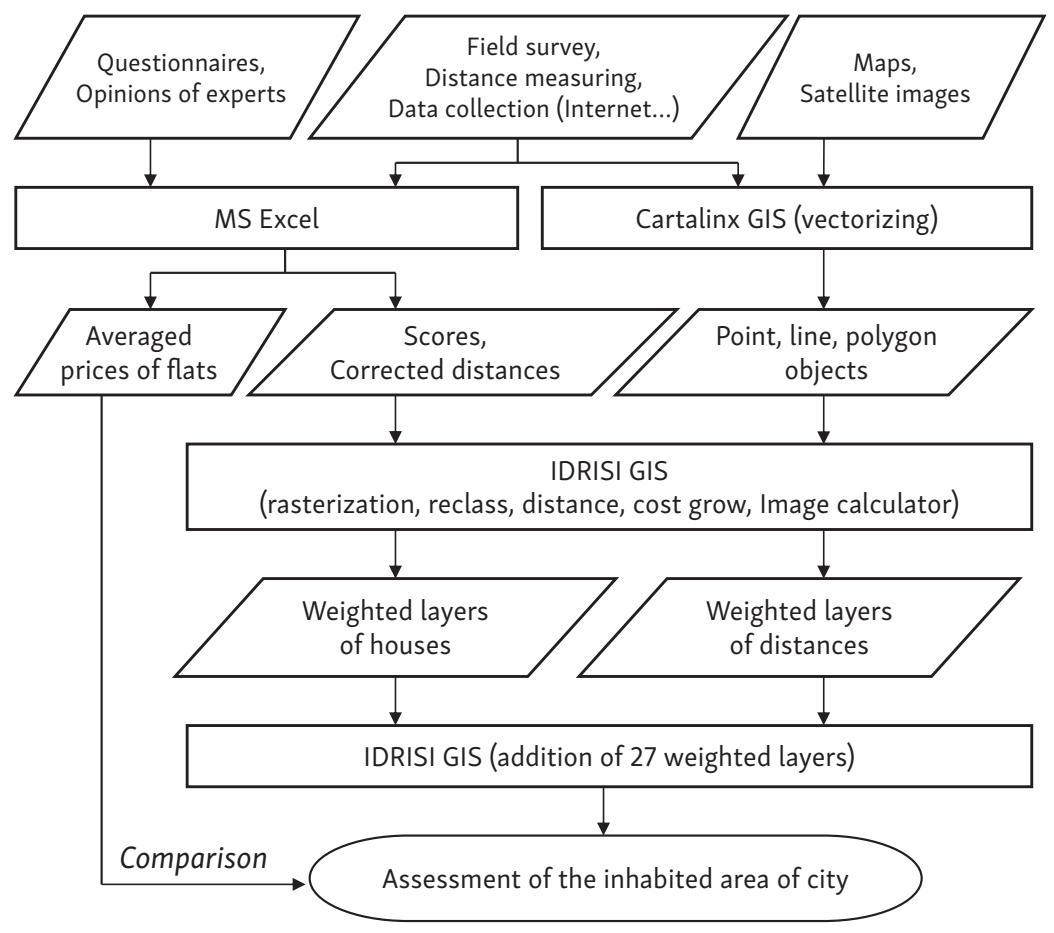

Fig. 4 - Flowchart model of the analytical procedures. Source: Gyenizse 2014.

trespass or jaywalk. It also support the use of the raster-based distance calculation methods, from which only the impassable routes were excluded ("h" = barriers).

Figure 3 illustrates a raster-based example, where the physical property-based (building material, type of heating, general condition of the building) ranking points (Chapter 2.1) are directly assigned to the pixels that represent dwellings, while no values are assigned to other, uninhabited objects.

The raster based layer of the assessment module was then generated by merging the 25 studied factors in 27 rasterized layers.

The generation of the liveability assessment model followed the data collection, analysis, visualisation and control procedure. The simplified flowchart of the model generation procedure is shown in Figure 4.

Firstly, property attributes that potentially influence residential property assessment and profoundly influence citizens' decision making policy, were surveyed with questionnaires and were selected by urban planning and GIS experts (Chapter 2.1).

By using analogue and digital maps, we analysed the spatial distribution of the infrastructural objects that may influence the value of the adjacent dwellings. The studied objects (point, line and polygon) were digitized in Cartalinx 
and subsequently were exported and integrated into IDRISI Selva software (Chapter 2.2).

With the aid of the questionnaire-based survey we classified the attributes and distances of services according to their negative or positive effect on their surroundings and also identified the magnitude of the effects. After processing the questionnaires (MS Excel) a relative ranking system was elaborated, and ranking values were assigned to dwellings, educational, infrastructural, traffic, sport and industrial services (Chapter 2.3).

After the revision of the residential and expert views on their residential areas we determined the magnitude and range of preference or non-preference impact of various infrastructural objects and services on their surroundings. These findings were then corrected for the raster-based calculations, while range limits were then converted to Euclidean distances (Chapter 2.4).

Vectorized layers of the object locations were then rasterized in IDRISI during which 27 weighted layers were generated. When all the 27 layers were averaged (reclassified) then the livability or dwelling preference assessment map was obtained. We differentiated to assessment map, one according to input of urban planner experts (expert range map or ER map) and a second one that was created based on the judgement of local residents (residential range map or residential range map; Chapter 2.5).

To validate the obtained assessment expert range and residential range maps, property prices were collected from online classified advertisements (Chapters 2.6 and 3.1).

\subsection{Studied parameters}

In order to assess the personal preference factors of the residential areas of Szeged, we mapped multiple physical objects and attributes. Personal preference factors were then evaluated based on their residential preferences. The selected objects and services may be indispensable destinations for local residents on a daily, weekly or monthly basis; furthermore, they may also contribute to residential mobility.

In order to select the list of relevant objects with significant impacts on property purchase, 316 residents of Pécs were interviewed. To evaluate the objects with the highest impact, we have selected a work committee with five members from the Institute of Geography at University of Pécs and local political leaders of the administrative government of Pécs. Due to the suggestion of the committee we omitted the occasionally and relatively rarely visited (on a monthly basis and annually) public objects, e.g. city hall, banks, museums and zoos. We also disregarded common, spatially densely located objects, like phone boxes, newspaper 
kiosks, parking lots, small stores and bars. We also did not consider the commuting distance between the place of residence and the work place. The selected factors objectively reflect typical urban conditions in Hungary and are representative for Eastern European cities of similar historical backgrounds. However, in different cultures and continents, different factors would be preferred and considered attractive, thus the number and type of personal preference factors would be likely different in the model. Factors that are most representative for the current Hungarian urban conditions are listed in column Studied parameters of Table 1.

Personal preference factors of the first class represent the general physical and infrastructural conditions of the properties as residents tend to own properties of higher living standards with low maintenance costs (Tóth, Keserü 2001; Rakonczai et al. 2009; Karancsi, Hornyák, Horváth 2012; Kovács et al. 2014).

The second class includes personal preference factors that are readily accessible with the means of public or individual transportation. The better accessibility may mean a substantial advantage but may include serious drawbacks, like higher traffic accident rates or the potential traffic jams.

The third class contains educational and cultural institutions. For families with small children, the proximity of day cares, kindergartens and high schools may pose favourable living conditions. The proximity of higher education institutions may provide extensive economic benefits for local residents, as houses or apartments are often rented out for students. Drawbacks of educational districts may include higher mean noise levels and increased traffic during drop-off and pick-up times.

The fourth class includes large commercial objects like farmer markets, malls, superstores and restaurants. Greater grocery stores and hypermarket chains provide a grand selection of everyday supplies and in most cases they are cheaper than small stores (Boros, Pál 2006).

The fifth class contains objects that are specialised for recreation, sport activities and large health care facilities. The proximity of hospitals is essential for elderly people and families with small children.

The sixth class includes three factors that are non-preferred by local residents. The proximity of industrial and factory plants and the associated heavy traffics have always been significant undesired factors for residents. Over the past decades, heavy traffic has become the largest air polluting and noise source (Kertész, Mezösi 1991). The largest pollutant sources in Szeged are the waste repository plant, the sewage treatment plant and the confined hog farm. Negative factors also include the presence of segregated and economically disadvantaged residents of low living standards in two locations within the administrative border of the city (Móraváros and the western districts of Kiskundorozsma).

Several studies indicate the importance of views and visual qualities for selecting the location of residence (Gyenizse et al. 2007, Gyenizse et al. 2013), however, 
Tab. 1 - Scores and distances associated with personal preference factors (see legend chapters 2.1. and 2.4.)

\begin{tabular}{|c|c|c|c|c|c|}
\hline \multirow[t]{2}{*}{ Studied parameters (personal preference factors) } & \multirow{2}{*}{$\begin{array}{l}\text { Relative } \\
\text { score }\end{array}$} & \multicolumn{2}{|c|}{ Residential review } & \multicolumn{2}{|c|}{ Experts' review } \\
\hline & & A & B & C & D \\
\hline \multicolumn{6}{|l|}{ Property attributes: } \\
\hline 1. Building material: brick (adobe, gas concrete) & 5.2 & - & - & - & - \\
\hline Ferroconcrete & -4.1 & - & - & - & - \\
\hline $\begin{array}{l}\text { 2. Availability of public utilities (electricity, } \\
\text { plumbing, sewerage) }\end{array}$ & 8.9 & - & - & - & - \\
\hline 3. Heating: distance (central) heating & 1.9 & - & - & - & - \\
\hline Individual heating & 6.8 & - & - & - & - \\
\hline 4. Needs for architectural and mechanical renewal & -5.2 & - & - & - & - \\
\hline 5. Own backyard & 5.7 & - & - & - & - \\
\hline \multicolumn{6}{|l|}{ Transportation: } \\
\hline 6. Proximity of bus, tram and trolley-bus stops & 5.8 & 404 & 257 & 500 & 341 \\
\hline 7. Proximity of local bus terminal & 2.0 & 1,700 & 1,397 & 2,000 & 1,661 \\
\hline 8. Proximity of highways of heavy traffic & -4.1 & 1,538 & 1,255 & 500 & 341 \\
\hline 9. Proximity of train station & -0.8 & 2,303 & 1,928 & 500 & 341 \\
\hline 10. Proximity of railroad & -4.1 & 2,193 & 1,831 & 500 & 341 \\
\hline \multicolumn{6}{|l|}{ Education and culture: } \\
\hline $\begin{array}{l}\text { 11. Proximity of day-cares, kindergartens, } \\
\text { elementary, middle and high schools }\end{array}$ & 2.7 & 1,342 & 1,082 & 1,000 & 781 \\
\hline 12. Proximity of college or university campuses & 1.8 & 3,436 & 2,925 & 2,000 & 1,661 \\
\hline 13. Proximity of churches & 2.1 & 1,096 & 866 & 1,000 & 781 \\
\hline 14. Proximity of downtown areas & 4.0 & 1,156 & 919 & 10,000 & 8,701 \\
\hline \multicolumn{6}{|l|}{ Commercial facilities: } \\
\hline $\begin{array}{l}\text { 15. Proximity of large grocery chains and farmer } \\
\text { markets }\end{array}$ & 5.9 & 586 & 417 & 1,000 & 781 \\
\hline 16. Proximity of hypermarkets and superstores & 3.5 & 1,077 & 849 & 1,000 & 781 \\
\hline $\begin{array}{l}\text { 17. Proximity of technical, decorator, furnisher, DIY } \\
\text { and gardening superstores and drug stores }\end{array}$ & 0.9 & 1,362 & 1,100 & 1,000 & 781 \\
\hline 18. Proximity of shopping malls & 1.1 & 1,051 & 826 & 10,000 & 8,701 \\
\hline 19. Proximity of large restaurants and eateries & 1.0 & 791 & 597 & 1,000 & 781 \\
\hline \multicolumn{6}{|l|}{ Recreation, sport and health care: } \\
\hline 20. Proximity of recreational parks & 7.4 & 794 & 600 & 1,000 & 781 \\
\hline $\begin{array}{l}\text { 21. Proximity of sport facilities (including aquatic) } \\
\text { and playgrounds }\end{array}$ & 1.7 & 1,006 & 787 & 1,000 & 781 \\
\hline 22. Proximity of hospitals and health care centres & 5.5 & 1,996 & 1,658 & 10,000 & 8,701 \\
\hline \multicolumn{6}{|l|}{ Industry and general environment: } \\
\hline 23. Proximity of industrial plants and parks & -5.9 & 5,138 & 4,423 & 500 & 341 \\
\hline 24. Proximity of air pollution, noise and stink sources & -7.9 & 5,472 & - & 1,000 & - \\
\hline $\begin{array}{l}\text { 25. Proximity of residential groups of } \\
\text { disadvantageous and low-income social status }\end{array}$ & -6.5 & 5,017 & 4,316 & 1,500 & 1,221 \\
\hline
\end{tabular}

Notes: A - Original longest distance (m), B - Corrected longest distance (m), C - Original longest distance (m), D Corrected longest distance $(\mathrm{m})$

Source: Gyenizse, Bognár 2014 
due to the almost complete flatness of the city, this factor has no relevant importance in Szeged.

\subsection{Collection of spatial data}

To collect spatial data, personal preference factors with fixed (physical) spatial coordinates were mapped. Shape identifiers of points, lines or polygons were assigned to each personal preference factor in the first column (Studied parameters) of Table 1.

With field monitoring we collected data in Hungarian countryside cities on the location of personal preference factors that is potentially important for the everyday life of local residents between 2011 and 2014. Buildings that require substantial reconstruction efforts were also identified and mapped, and negative scores were assigned to them.

By using data from analogue and digital maps and Google Earth satellite images, residential buildings, industrial and sport facilities, traffic routes and parks were vectorised.

GIS analyses were taken using EOV coordinate system (Hungarian datum 1972, (Description directory of the Hungarian Geodetic Reference). The base map was the digitized and georeferred version of the 1:10,000 map that reflects the 1984 topographic conditions. The satellite images of the Google Earth (downloaded on June 20,2014) were georeferred to these maps. We also incorporated the vectorised database of the Openstreetmap for Hungary (downloaded on July 29, 2014). However, this latter database only indicated about one tenth of the residential properties. For this reason the exact identification of the individual objects was done by field survey, internet based images and the printed city maps of Szeged. The digitization of the objects was done with Cartalinx software.

By using online resources, the educational, cultural, medical and other provider and public supply facilities were identified. In total we vectorised 651 points, 384 lines and 3,047 polygon objects (Fig. 5).

The digitized objects were stored on 27 vectorized layers, where one personal preference factor represented one layer. These vector-based layers were later rasterized with Idrisi Selva software (Chapter 2.5).

\subsection{Collection of data attributes}

As the main objective of the current study was not only the spatial visualisation of the personal preference factors but also the spatial analysis of their impact on residential distribution and living standards. To achieve this goal, relative scores 


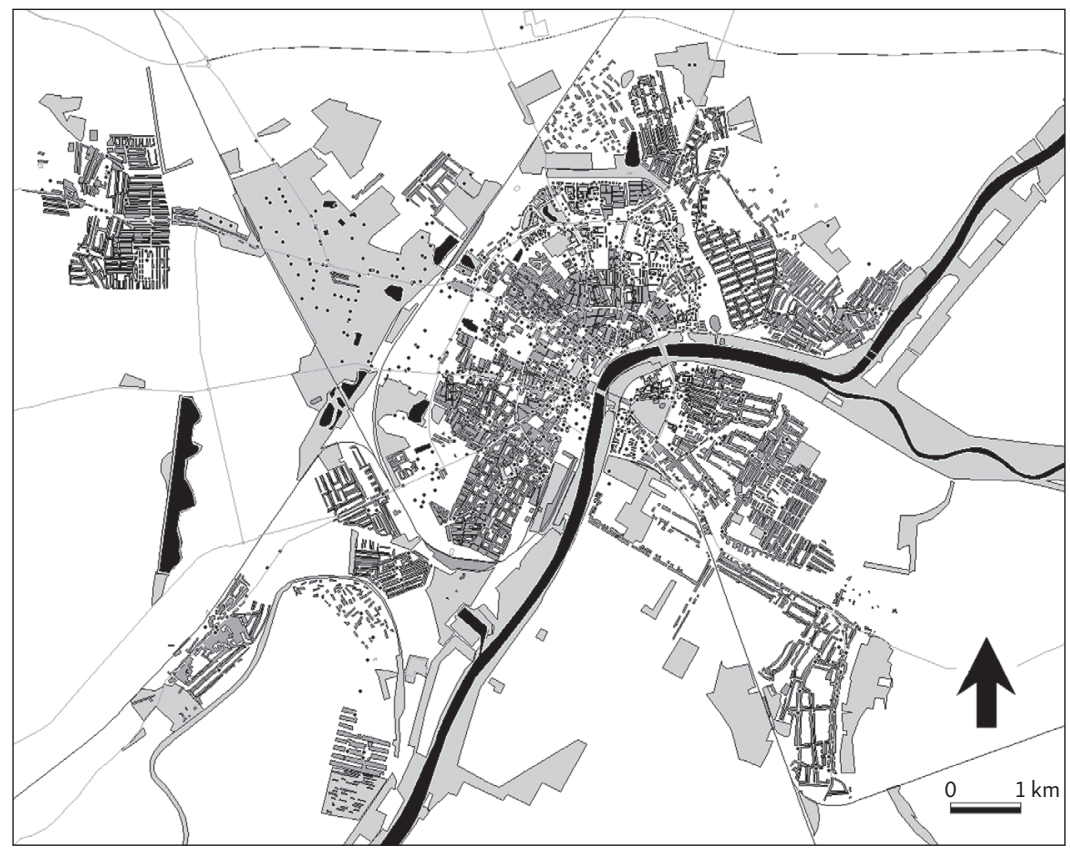

Fig. 5 - Visualization of digitised points, lines and polygons. Source: Gyenizse 2014.

were given to each attribute. The attribute evaluation was based on interviews during which 1,660 people were interviewed between 2009 and 2012 in Hungarian countryside cities (Gyenizse 2013). Only residents older than 18 years and approximately 1 to $2 \%$ of the total population of the cities were interviewed. The interviewed residents' age distribution was representative for the demographics of the given city. The questionnaire survey primarily focused on the importance of the proximity of the personal preference factor objects to the place of residence, i.e. how important the distance of the given personal preference factor for the responders was.

The order of importance of the 25 factors listed in Table 1 was surveyed in the questionnaire. The question read as follows: If you decide to move out from your current place of residence, to what degree would your decision be influenced by the following personal preference factors? Please give scores to each personal preference factors. Scores were determined according to the order of preference as follows: -2 (strongly disadvantageous), -1 (slightly disadvantageous), 0 (indifferent), 1 (beneficial), 2 (really attractive). Solely due to psychological concerns, negative numbers were involved in the survey. Obtained data were then analysed in MS Excel.

Following the processing of the questionnaires, the theoretical extreme (lowest and highest) values of the personal preference factor ranged between $-3,320$ and 
$+3,320$. As these scores were unnecessarily high, the values were reclassified to range between -10 and +10 . Thus the theoretical lowest and highest values would have reached -270 and +270 , respectively. This range was sufficiently broad for the sound evaluation of the urban areas, thus no broader scale was needed for the assessment (Column Relative score, Table 1).

\subsection{Personal preference factor ranges and their correction}

The majority of the obtained GIS layers were weighted by (inverse) distance from the personal preference factor of interest. The positive or negative effect of the assessed personal preference factors weakens with increasing distance, and above a given threshold distance (range) their impact ceases. For this reason we defined the spatial boundaries of each factor, which was achieved with two methods.

Firstly, we determined the personal preference factor ranges based on the questionnaire survey. Responders provided the walking distance along roads and sidewalks, i.e. not the Euclidean distances, the walking or driving distances to the given object, which formed the basis of the residential range map. However, many distances were provided inaccurately by the responders, even when maps were used (Column Residential review, Original longest distance, Table 1).

We also employed a second method for the measurement of range. The accuracy of the relative scoring system, the weighting system and the threshold distances were also evaluated by experts, including eight geographers/urbanists, GIS experts and local administrative leaders. Following our presentation at the Urban Geographical Conference (2012) in the city of Bük, Hungary, the range of personal preference factors were determined with the contribution of the participating urban geographers. Ultimately alternate ranges were set based on these evaluations and hereafter called expert range (expert range map, Column Experts' review, Original longest distance, Table 1).

Statistical methods were then applied to verify and compare the models of different range determination methods with the real spatial distribution of property values and prices (Chapter 3.1).

Next, we carried out a range correction procedure on both the expert range and residential range maps. It was essential due to the 10 meter per pixel resolution of the map. Since we could not consider each house and yard as artificial obstruction, thus their impact on the range was corrected with statistical procedures.

Nevertheless, when ranges are visualised cartographically, the problem of the difference between the Euclidean and Manhattan distances arises. Among the analysed factors, only air pollution, stink and noise spread unhampered. However, in all other cases Manhattan distances represent the real travel distances. As the liveability assessment of residential areas was done on raster layers, the delineation 
of the impact ranges had to be harmonised with the conventional route-planning algorithms. We had to find a correlation, which enables the conversion of Euclidian distances to Manhattan distances on raster layers.

To find a representative correlation between Euclidian and Manhattan distances in cities of the Great Hungarian Plain, 862 measurements were carried out on the city maps of Szeged, Debrecen and Kecskemét (cities of similar morphological and genetic properties). The shortest distances were measured with Google Earth route planner (pedestrian settings) between two points of known distances (from 500 to $5,000 \mathrm{~m}$ in $500 \mathrm{~m}$ increments).

Our measurements were controlled with the network analyst application of the Qgis software on the OpenStreetMap street network of Szeged by carrying out 1,023 measurements. The difference between two measurement series was low, with a mean values of $-3.5 \%$ (with highest and lowest being $-5.7 \%$ and $-1.6 \%$, respectively). Consequently the distance measurement procedures of the Google Earth are sufficiently accurate for the Hungarian street networks when done at large numbers and they are also applicable for other similar urban areas.

Based on the obtained data a close relationship was observed between the Euclidian and Manhattan distances with a correlation coefficient of $r^{2}=0.9998$. To convert Euclidean distances to Manhattan-corrected Euclidian distances the following equation was used: $y=0.88 x-98.587$, where $y$ is the Euclidean distance and $\mathrm{x}$ is the Manhattan-corrected Euclidean distance (shortest path). With the equation of the obtained linear relationship we calculated the Manhattan distances from the Euclidian distances. The calculated distances are shown in columns Residential review, Corrected longest distance and Experts' review, Corrected longest distance in Table 1.

\subsection{Data analysis in GIS environment}

The surveyed point, line and polygon shape objects were vectorised by using Cartalinx mapping software. Vectorised data were then rasterised with Idrisi Selva software, where rasterised pixel sizes were set to $10 \times 10$ meters in order to maintain a relatively low calculation time. Relative score values and the adjustment of range were done in multiple steps. Reclassification of the score values of the relevant factors was done most easily for the sharply delineated objects (residential properties).

When distance from the objects was relevant, a more complex method was used to calculate ranking. In this case a map layer was created, in which each pixel was given a distance value that increased with growing distance from the object of interest. In the next step, range was given to the program, and then the distance was converted to score value with the Image Calculator module. Following the 
Tab. 2 - Collected prices of residential properties (HUF/m²)

\begin{tabular}{|c|c|c|c|c|c|c|}
\hline $\begin{array}{l}\text { City zones } \\
\text { (Fig. 2) }\end{array}$ & $\begin{array}{l}\text { Number of sold } \\
\text { residentals }\end{array}$ & Average & Standard deviation & Minimum & Maximum & $\begin{array}{l}\text { Standard deviation } \\
\text { / Average } \times 100\end{array}$ \\
\hline 1 & 57 & $231,954.0$ & $57,128.2$ & $133,333.3$ & $412,500.0$ & 24.6 \\
\hline 2 & 115 & $205,678.0$ & $61,055.1$ & $78,947.4$ & $358,490.6$ & 29.7 \\
\hline 3 & 101 & $207,640.3$ & $61,880.2$ & $77,245.5$ & $379,047.6$ & 29.8 \\
\hline 4 & 67 & $204,031.3$ & $55,243.8$ & $95,769.2$ & $340,440.0$ & 27.1 \\
\hline 5 & 84 & $204,796.9$ & $58,164.6$ & $80,357.1$ & $555,185.2$ & 28.4 \\
\hline 6 & 95 & $221,041.9$ & $64,552.9$ & $75,000.0$ & $383,333.3$ & 29.2 \\
\hline 7 & 80 & $210,639.7$ & $45,110.1$ & $122,272.7$ & $383,333.3$ & 21.4 \\
\hline 8 & 66 & $233,108.3$ & $56,900.3$ & $131,578.9$ & $416,666.7$ & 24.4 \\
\hline 9 & 28 & $188,133.6$ & $78,925.6$ & $89,361.7$ & $366,911.8$ & 42.0 \\
\hline 10 & 8 & $220,917.4$ & $80,933.1$ & $116,666.7$ & $310,294.1$ & 36.6 \\
\hline 11 & 26 & $224,085.8$ & $60,981.2$ & $127,777.8$ & $423,076.9$ & 27.2 \\
\hline 12 & 28 & $187,410.0$ & $69,521.0$ & $101,568.6$ & $356,122.4$ & 37.1 \\
\hline 13 & 30 & $190,635.8$ & $54,628.5$ & $99,230.8$ & $314,000.0$ & 28.7 \\
\hline 15 & 27 & $175,483.5$ & $56,826.5$ & $85,576.9$ & $315,151.5$ & 32.4 \\
\hline 16 & 5 & $187,563.9$ & $38,734.4$ & $147,407.4$ & $249,375.0$ & 20.7 \\
\hline 17 & 5 & $143,964.6$ & $8,857.7$ & $134,444.4$ & $153,076.9$ & 6.2 \\
\hline 18 & 30 & $164,667.0$ & $59,411.6$ & $79,333.3$ & $316,129.0$ & 36.1 \\
\hline 19 & 5 & $186,568.6$ & $38,592.7$ & $147,872.3$ & $232,500.0$ & 20.7 \\
\hline 20 & 9 & $181,668.5$ & $55,267.6$ & $103,478.3$ & $287,416.7$ & 30.4 \\
\hline 21 & 16 & $143,372.4$ & $41,583.9$ & $72,500.0$ & $241,836.7$ & 29.0 \\
\hline 22 & 70 & $177,055.0$ & $43,279.6$ & $101,886.8$ & $259,000.0$ & 24.4 \\
\hline 23 & 57 & $158,685.3$ & $23,327.9$ & $111,666.7$ & $216,363.6$ & 14.7 \\
\hline 24 & 22 & $139,867.7$ & $19,501.7$ & $112,741.9$ & $185,555.6$ & 13.9 \\
\hline 25 & 67 & $204,856.6$ & $43,400.5$ & $115,000.0$ & $291,176.5$ & 21.2 \\
\hline 26 & 27 & $142,994.4$ & $17,888.2$ & $91,176.5$ & $179,245.3$ & 12.5 \\
\hline 27 & 9 & $147,212.1$ & $35,179.3$ & $111,250.0$ & $223,333.3$ & 23.9 \\
\hline 28 & 22 & $169,359.8$ & $30,244.7$ & $137,254.9$ & $278,000.0$ & 17.9 \\
\hline 31 & 79 & $203,962.7$ & $40,018.2$ & $109,289.6$ & $310,000.0$ & 19.6 \\
\hline 35 & 42 & $144,511.3$ & $41,343.9$ & $88,709.7$ & $265,000.0$ & 28.6 \\
\hline 40 & 23 & $228,847.5$ & $67,550.0$ & $150,810.8$ & $373,750.0$ & 29.5 \\
\hline 42 & 7 & $145,070.7$ & $52,700.7$ & $83,333.3$ & $243,891.4$ & 36.3 \\
\hline 43 & 3 & $169,520.8$ & $28,743.8$ & $146,551.7$ & $201,754.4$ & 17.0 \\
\hline
\end{tabular}

Source: Bognár 2015

reclassification, the distance value was a positive number when the value monotonously decreased with increasing distance from the object. When the distance was a negative number then the distance value gradually increased to the maximum range value. This calculation procedure was carried out with the residential ranges as well as with those calculated by the experts.

Several physical objects in Szeged may hinder direct transportation forcing the traveller for detours of more than a few blocks. These obstacles were mapped in IDRISI software environment. The Cost Grow module of IDRISI was used to 
calculate the Manhattan-corrected shortest distances as they account for the input transportation obstacles during the route planning procedure.

By generating layers for each personal preference factors, the five residential property types and 20 distance-weighted layers were summed in the Image calculator module. Seven map layers outline the contour of the residential properties, while the other 20 map layers characterise the entire studied area as a function of distance form a given personal preference factor object. Sums were generated with both range types. This way we obtained two types of liveability assessment maps for Szeged, the residential range (RR) and the expert range (ER) maps.

\subsection{Validation}

To validate model data, we collected the average prices of properties per unit area from various districts of Szeged (Tab. 2). We have collected and processed 1,310 property advertisements. Property prices were assumed to indicate or adequately represent the personal preference factors of the given property or district.

By analysing the property market in Hungary some difficulties may arise. Theoretically, there is a possibility to use the database of the Duty Office (Department of Revenue), however, since the selling of new dwellings is tax-free, thus it only contains information on used dwellings. Because of the overall and very common pursuit for tax avoidance, purchase contracts normally indicate lower prices than agreed between seller and buyer, to reduce the amount of tax. Thereafter, in the most valuable segment of the market, customers are rather companies than individuals (even the property actually used for living), and these transactions do

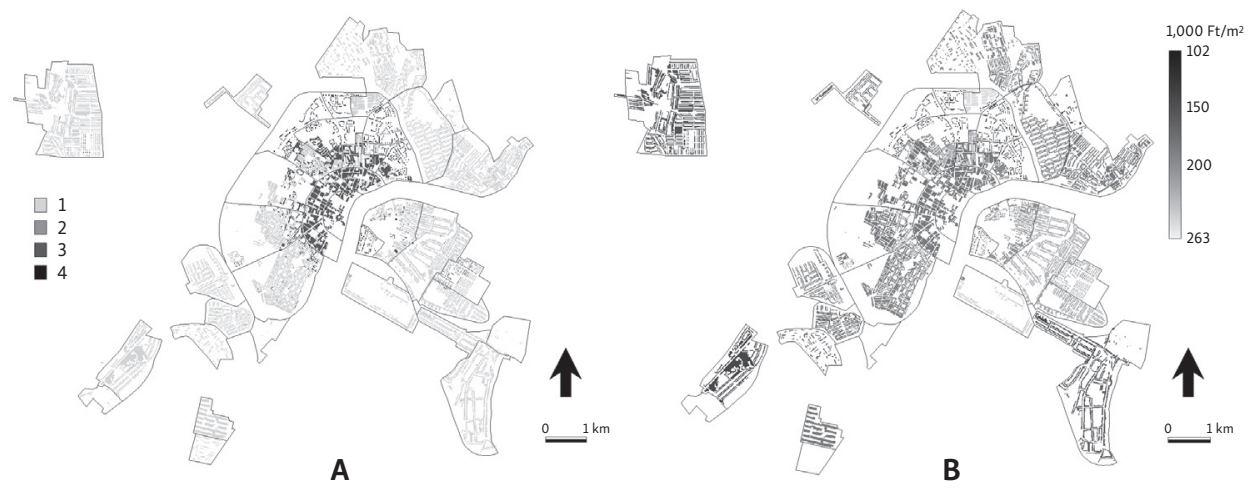

Fig. 6 - Types of residential properties in Szeged (A) and the average unit property price in each district of the city (B). 1 - family house, 2 - terrace house, 3 - brick apartment, 4 - concrete (block house) apartment. Source: Gyenizse 2014. 
not appear in these sources (Székely 2008). Because of these obstructions, there is a relatively small number of research papers available on the spatial distribution of marketable properties in Hungary. Some assumes the controversies and uses the official data (see for example Tánczos-Szabó, Brindza 2014), while others, like ourselves, collect a more exact database from classifieds (Horváth et al. 2013, Mezö 2013). This latter method also has the advantage of containing hints for some qualitative aspects of the properties.

First, we classified the residential properties of Szeged into four categories based on field surveys, city maps and Google Earth Satellite images. The obtained classes are family houses, terraced houses, brick apartments and concrete (block house) apartments (Fig. 6A). Data on property prices were collected from internet classifieds, since we did not have access to prices claimed in legal contracts. For a given city district an average price was then determined for all four property types. We also calculated the areal proportion of the four property types with Idrisi software, and area-based weighted average property prices were then determined for each city district.

\section{Results and conclusions}

\subsection{Comparison of the two liveability assessment maps}

Figures 7A and 7B show the results of the data collection and analyses phases when the 25 personal preference factors were summed. The sum of the personal preference factors visualised those layers that solely refer to residential properties (5 layers) and also those that have distance-dependent scores (20 layers). Consequently, pixels that represent residential districts were calculated from all 25 personal preference factors, while the values of the other pixels were determined by weighting distance from the object of interest.

Significant differences are observed between the residential range and expert range maps. The minimum and maximum pixel values on the residential range map were -6.0 and 34.2 , respectively, while pixel values on the expert range map ranged between 0.6 and 49.9. For all pixels, residential range pixel values were lower than the corresponding expert range map values with a maximum score difference of 31.1 points. Further statistical information are shown in Table 3.

To validate the obtained residential range and expert range liveability assessment maps, they were compared and correlated visually and statistically with the property unit price map. Property prices are usually considered to be representative to reflect the personal preference factors of the given realty or residential district.

Since no street names or house numbers are shown in the classified advertisements, our statistical analyses had to be carried out at district level. Since we did 
Tab. 3 - District-level statistical data based on the expert range and residential range maps

\begin{tabular}{|c|c|c|c|c|c|c|c|c|c|c|}
\hline \multirow[b]{2}{*}{$\begin{array}{l}\text { City zones } \\
\text { (Fig. 2) }\end{array}$} & \multicolumn{5}{|c|}{ Residential range map } & \multicolumn{5}{|c|}{ Expert range map } \\
\hline & $\begin{array}{l}\text { Mini- } \\
\text { mum }\end{array}$ & $\begin{array}{l}\text { Maxi- } \\
\text { mum }\end{array}$ & Average & Range & $\begin{array}{l}\text { Standard } \\
\text { deviation }\end{array}$ & $\begin{array}{l}\text { Mini- } \\
\text { mum }\end{array}$ & $\begin{array}{l}\text { Maxi- } \\
\text { mum }\end{array}$ & Average & Range & $\begin{array}{l}\text { Standard } \\
\text { deviation }\end{array}$ \\
\hline 1 & -2.10 & 31.45 & 12.07 & 33.55 & 8.71 & 0.00 & 47.00 & 26.60 & 47.00 & 10.82 \\
\hline 2 & -8.38 & 34.24 & 10.84 & 42.62 & 9.98 & 9.64 & 49.47 & 27.51 & 39.83 & 9.45 \\
\hline 3 & -20.85 & 26.14 & -4.44 & 46.98 & 11.65 & -2.09 & 49.86 & 17.38 & 51.95 & 13.94 \\
\hline 4 & -16.51 & 25.31 & -3.59 & 41.82 & 9.45 & 0.00 & 42.60 & 12.84 & 42.60 & 11.25 \\
\hline 5 & -17.42 & 25.81 & -4.69 & 43.24 & 9.41 & 0.00 & 46.19 & 13.84 & 46.19 & 10.38 \\
\hline 6 & -7.48 & 28.64 & 6.72 & 36.12 & 9.98 & 10.11 & 44.05 & 26.51 & 33.94 & 9.98 \\
\hline 7 & -9.17 & 29.22 & 8.74 & 38.39 & 9.74 & 0.00 & 43.02 & 26.06 & 43.02 & 9.60 \\
\hline 8 & -17.99 & 22.04 & 0.17 & 40.03 & 11.16 & -1.62 & 42.54 & 20.67 & 44.16 & 11.71 \\
\hline 9 & -1.01 & 30.36 & 14.23 & 31.37 & 10.11 & 14.18 & 45.78 & 29.43 & 31.60 & 10.89 \\
\hline 10 & -19.16 & 16.99 & -7.86 & 36.15 & 7.56 & -1.89 & 37.81 & 12.65 & 39.70 & 7.85 \\
\hline 11 & -11.36 & 20.05 & -2.52 & 31.40 & 9.46 & 6.56 & 42.26 & 18.81 & 35.71 & 10.03 \\
\hline 12 & -14.40 & 24.47 & 1.24 & 38.86 & 11.07 & 0.64 & 41.68 & 18.23 & 41.03 & 11.35 \\
\hline 13 & -11.56 & 24.97 & -0.71 & 36.53 & 9.84 & 5.23 & 44.13 & 18.94 & 38.89 & 10.26 \\
\hline 15 & -17.85 & 24.99 & -5.07 & 42.84 & 9.88 & -1.35 & 38.01 & 13.40 & 39.36 & 9.99 \\
\hline 16 & -13.10 & 17.53 & -3.22 & 30.63 & 9.82 & 9.94 & 41.57 & 20.03 & 31.64 & 9.87 \\
\hline 17 & -7.47 & 23.75 & 7.03 & 31.22 & 11.00 & 4.36 & 34.82 & 19.06 & 30.47 & 10.94 \\
\hline 18 & -16.31 & 19.99 & -4.81 & 36.30 & 9.73 & -2.86 & 35.95 & 10.97 & 38.82 & 10.00 \\
\hline 19 & -16.50 & 20.37 & -3.96 & 36.87 & 10.74 & 4.30 & 42.74 & 19.87 & 38.43 & 10.94 \\
\hline 20 & -20.87 & 13.94 & -9.64 & 34.81 & 8.85 & -1.15 & 36.35 & 14.20 & 37.50 & 9.19 \\
\hline 21 & -17.58 & 18.67 & -1.50 & 36.25 & 10.59 & -6.74 & 32.98 & 12.51 & 39.72 & 11.34 \\
\hline 22 & -4.91 & 28.23 & 3.86 & 33.13 & 6.06 & 10.35 & 46.98 & 20.60 & 36.64 & 6.05 \\
\hline 23 & -1.38 & 22.17 & 5.64 & 23.55 & 3.31 & 0.00 & 39.63 & 21.18 & 39.63 & 3.46 \\
\hline 24 & -5.64 & 25.01 & 4.71 & 30.65 & 4.18 & 9.83 & 43.18 & 21.17 & 33.36 & 3.73 \\
\hline 25 & -6.24 & 20.54 & 2.83 & 26.78 & 5.79 & 0.00 & 43.80 & 20.43 & 43.80 & 7.64 \\
\hline 26 & -12.27 & 12.67 & -4.39 & 24.95 & 4.11 & 0.00 & 34.38 & 12.76 & 34.38 & 5.98 \\
\hline 27 & -19.32 & 12.94 & -9.39 & 32.26 & 10.24 & -4.22 & 25.93 & 7.04 & 30.15 & 10.27 \\
\hline 28 & -8.98 & 24.42 & 1.26 & 33.40 & 5.89 & 10.35 & 46.37 & 22.44 & 36.01 & 6.97 \\
\hline 31 & -8.22 & 30.33 & 4.16 & 38.54 & 9.12 & 4.26 & 49.99 & 23.37 & 45.73 & 9.44 \\
\hline 35 & -19.02 & 15.94 & -6.08 & 34.96 & 10.49 & -14.21 & 35.35 & 9.44 & 49.56 & 12.00 \\
\hline 37 & -15.75 & 17.01 & -9.43 & 32.76 & 4.67 & -7.90 & 28.89 & 0.53 & 36.79 & 5.55 \\
\hline 38 & -18.69 & 3.30 & -13.95 & 21.99 & 2.91 & 0.06 & 24.84 & 6.82 & 24.78 & 2.45 \\
\hline 39 & -4.40 & 19.84 & 1.20 & 24.24 & 5.94 & 4.55 & 28.66 & 10.10 & 24.12 & 5.96 \\
\hline 40 & -16.24 & 15.42 & -4.47 & 31.66 & 10.34 & 0.43 & 39.21 & 15.81 & 38.78 & 10.63 \\
\hline 41 & -13.37 & 16.10 & -7.75 & 29.46 & 4.41 & -0.17 & 29.38 & 5.73 & 29.55 & 4.76 \\
\hline 42 & -12.28 & 12.54 & -9.83 & 24.83 & 4.10 & 1.51 & 29.28 & 6.33 & 27.76 & 4.38 \\
\hline 43 & -12.56 & 13.41 & -6.41 & 25.97 & 5.99 & 3.41 & 35.30 & 12.65 & 31.89 & 6.33 \\
\hline
\end{tabular}

Source: Gyenizse 2015

not find properties for sale in each street, we had to compare the model results with the real prices at district level. Consequently, the property unit price map has district-level spatial resolution, i.e. average property prices are shown at district level. In order to compare the residential range and expert range maps with 


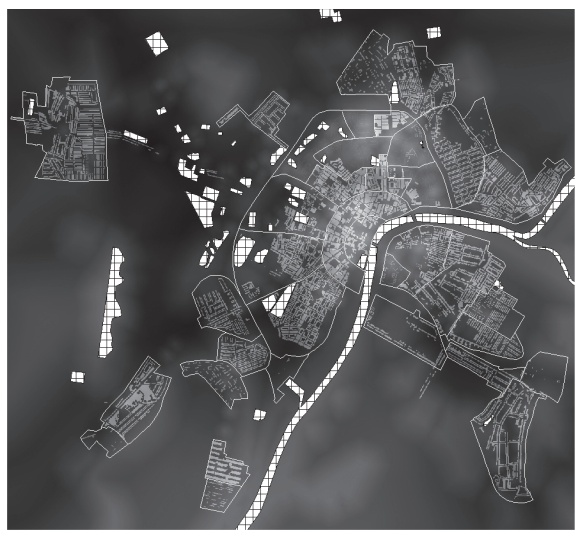

A

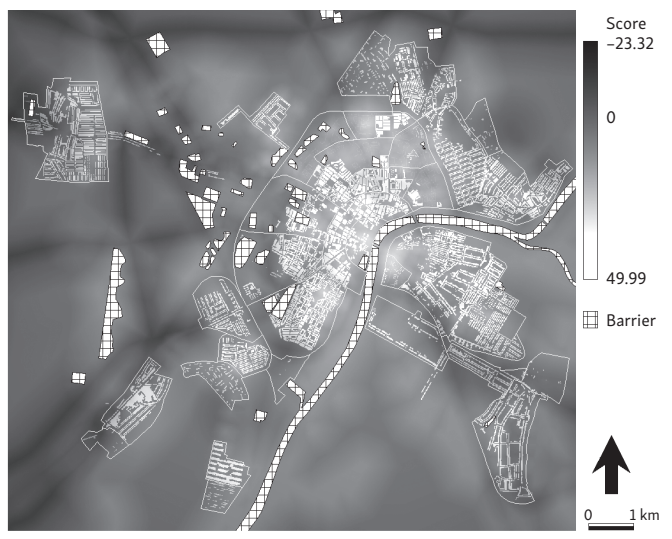

B

Fig. 7 - The obtained residential range (A) and expert range (B) maps after summing up the individual values of the 25 personal preference factors. Source: Gyenizse 2014.
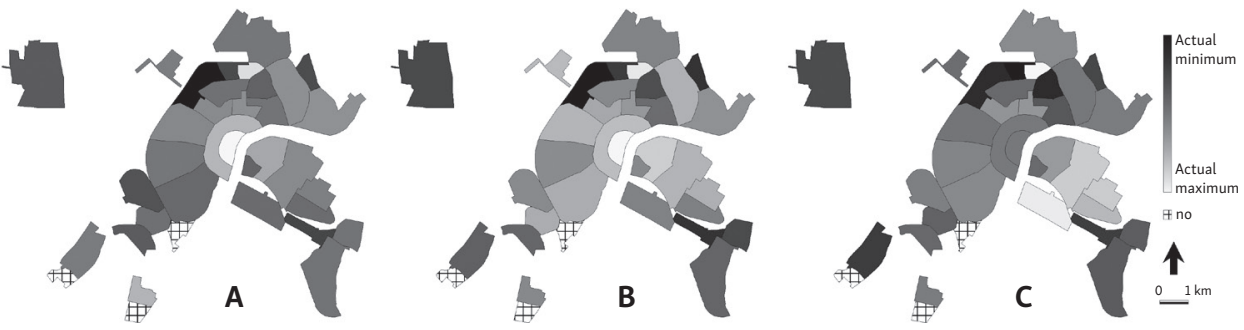

Fig. 8 - The residential range (A), expert range (B) and property unit price (C) maps, no data ("no"). Source: Gyenizse, Bognár 2014.

the property unit price map, the spatial resolution of the residential range and expert range maps were decreased to district levels (Fig. 8). To further increase comparison efficiency, the residential range and expert range maps were rescaled between the actual minimum and maximum values.

Maps had to be rescaled for visual comparison. If the assessment maps are compared with the mean property prices of the urban districts of Szeged, the general pattern is similar, with minor differences in places. Highest property prices are found in new family house dominated districts, with highest prices in the Fodor kert and Füvészkert districts, while somewhat lower prices are found in the downtown area. Compared to model assessment values, higher property prices have been found over the past few years in the Ujjszeged and Marostő districts. Lowest mean property prices are generally found in blockhouse districts (Tarján, Makkosháza, Újrókus), and the semirural district of Szentmihály. Purely based on visual interpretation, however, it is challenging to further compare the spatial 
distribution of property and real estate prices between the model-generated and real map.

To overcome the aforementioned challenge, linear and rank correlations, as well as significance levels were calculated between the residential range and property unit price, and the expert range and property unit price maps. Correlation coefficient between the residential range and the property unit price maps and the expert range and property unit price maps were 0.55 and 0.72 , respectively. As the significance level was high (99.99\%) a strong correlation exists between the compared datasets.

Based on our findings we conclude that the expert range results are more closely related to the spatial pattern of the property prices than the residential range maps. For this reason, hereafter we only analyse and discuss the results of the expert range map.

\subsection{Detailed analysis of the low-score districts}

Besides the profound analysis of the complex assessment model, the results of the individual map layers of each 25 personal preference factors were also analysed. These data may bear important information not only on the location of low-cost properties, but may explore the reason behind their low value and score. By having these data, the individual factors can be analysed and plans could be elaborated in order to explore the role of the individual factors and to determine the need for a given personal preference factor reconditioning or state improvements. To achieve this goal, we determined the relative scores of the lowest $3 \%$, and then, by reclassifying the map we defined the location of these property estates. These districts are located at different parts of Szeged, and they were classified into 15 clearly-delineated groups (Fig. 9).

Based on the spatial pattern of the lowest 3\% pixel values within Szeged, many different types of residential areas are found in this low-score group. The first group of these properties is located in the northern part of Szeged and is dominated by concrete apartment block houses. The second property types are low-cost properties found in the outskirts of the city. The third group comprises miscellaneously developed suburban areas of family and weekend (second) houses located along the city boundaries.

In order to explore the reason for the existence of low-score districts individual mean personal preference factor values were determined for each layer with the Over Time Series function of the Profile Module (Table 4).

This way we analysed the socio-economic problems of the low-score districts. Although they have different origins, there are two principal reasons behind the low scores: (i) there are multiple non-preferred personal preference factors 

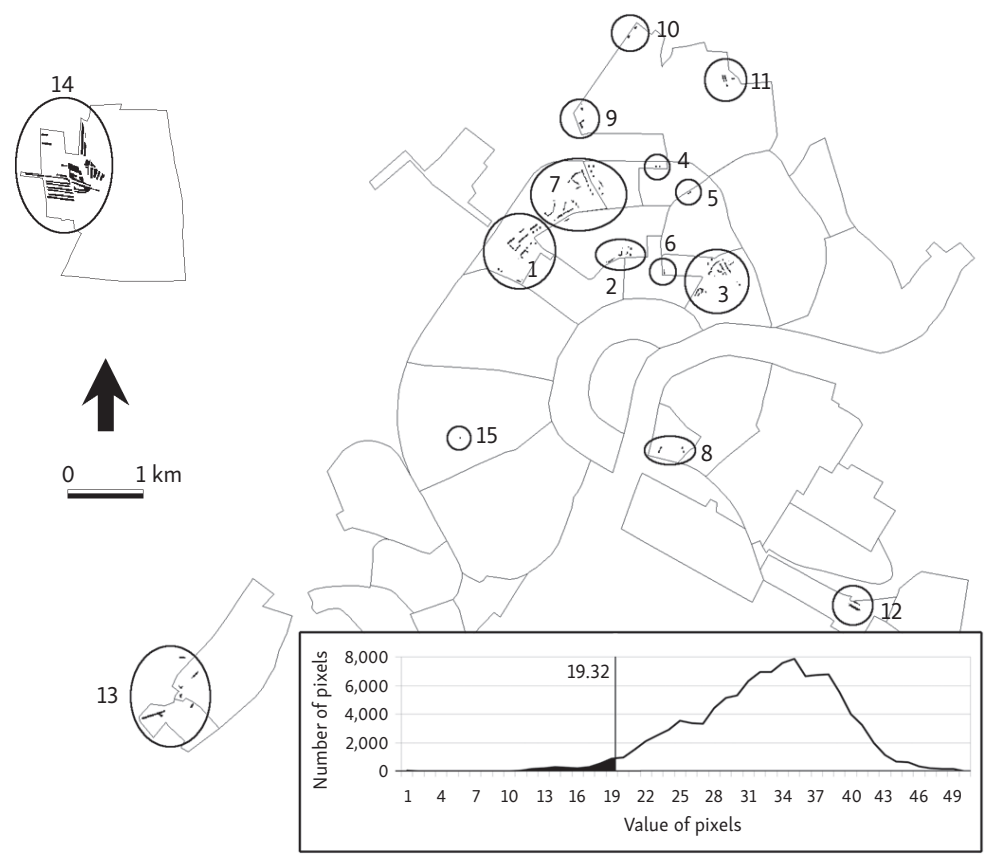

Fig. 9 - The location of the buildings with the lowest 3\% pixel scores. Source: Gyenizse 2014.

located in these districts, (ii) there are a low number of attractive personal preference factors, or the distant positive personal preference factors do not reach these zones, and they are characterised by relatively low values. Table 4 summarises the negative (non-preferred) factors in gray cells and positive personal preference factors in italic characters. Personal preference factors with no impact on a given district are indicated by a pixel value of 0 . These latter personal preference factors do not have any impact on their surroundings as they are located at a farther distance than the actual range of the studied spatial factor.

By analysing the districts of the lowest scores in details we outlined two marked development types and the list of characteristic problems. Columns 1 to 8 in Table 4 indicate block house-type development styles. These concrete apartment houses are distinctive building types and characters of the post-socialist countries and their urban transition, their complex problems are often discussed (Kovács, Douglas 1996; Egedy 2000).

In our liveability assessment survey, among the personal preference factors of the questionnaire list, low scores were given to questions on the general assessment of the physical properties of concrete apartments. One reason for these low scores is that spacious green areas among the blockhouses cannot compensate sufficiently the non-preference of the living conditions of these apartment types and 
Tab. 4 - The detailed presentation of the relative scores of those inhabited areas, which have the lowest pixel values

\begin{tabular}{|c|c|c|c|c|c|c|c|c|c|c|c|c|c|c|c|}
\hline \multirow[t]{2}{*}{$\mathrm{N}$} & \multicolumn{15}{|c|}{ District numbers (for the corresponding numbers see Fig. 9) of the lowest $3 \%$ pixel values } \\
\hline & 1 & 2 & 3 & 4 & 5 & 6 & 7 & 8 & 9 & 10 & 11 & 12 & 13 & 14 & 15 \\
\hline 1 & -4.1 & -4.1 & -4.1 & -4.1 & -4.1 & -4.1 & -4.1 & -4.1 & 5.2 & 5.2 & 5.2 & 5.2 & 5.2 & 5.2 & 5.2 \\
\hline 2 & 8.9 & 8.9 & 8.9 & 8.9 & 8.9 & 8.9 & 8.9 & 8.9 & 5.9 & 5.9 & 5.9 & 5.9 & 5.7 & 8.7 & 5.9 \\
\hline 3 & 1.9 & 1.9 & 1.9 & 1.9 & 1.9 & 1.9 & 1.9 & 1.9 & 6.8 & 6.8 & 6.8 & 6.8 & 6.8 & 6.8 & 6.8 \\
\hline 4 & 0.0 & 0.0 & 0.0 & 0.0 & 0.0 & 0.0 & 0.0 & 0.0 & 0.0 & 0.0 & 0.0 & 0.0 & 0.0 & -0.2 & -5.2 \\
\hline 5 & 0.0 & 0.0 & 0.0 & 0.0 & 0.0 & 0.0 & 0.0 & 0.0 & 5.7 & 5.7 & 5.7 & 5.7 & 5.7 & 5.7 & 5.7 \\
\hline 6 & 2.8 & 3.9 & 3.1 & 0.0 & 1.8 & 5.1 & 3.2 & 2.6 & 0.0 & 0.0 & 0.0 & 0.4 & 1.0 & 0.6 & 0.7 \\
\hline 7 & 0.4 & 0.6 & 1.0 & 1.0 & 1.5 & 1.0 & 1.4 & 0.0 & 1.1 & 0.0 & 0.0 & 0.0 & 0.0 & 0.0 & 0.0 \\
\hline 8 & -3.0 & -2.9 & -3.5 & 0.0 & -3.8 & -3.7 & -2.7 & -1.5 & -3.2 & 0.0 & -1.0 & -3.7 & -2.2 & -2.1 & -3.9 \\
\hline 9 & 0.0 & 0.0 & 0.0 & 0.0 & 0.0 & 0.0 & 0.0 & -0.2 & 0.0 & 0.0 & 0.0 & 0.0 & -0.1 & 0.0 & 0.0 \\
\hline 10 & -0.1 & 0.0 & 0.0 & 0.0 & 0.0 & 0.0 & 0.0 & -2.4 & -2.4 & -3.7 & 0.0 & 0.0 & -2.0 & 0.0 & 0.0 \\
\hline 11 & 2.3 & 2.2 & 2.0 & 1.5 & 2.4 & 2.2 & 1.9 & 2.3 & 0.1 & 0.0 & 0.0 & 0.0 & 0.2 & 1.0 & 1.3 \\
\hline 12 & 0.5 & 0.6 & 0.2 & 0.0 & 0.0 & 0.6 & 0.1 & 1.2 & 0.0 & 0.0 & 0.0 & 0.0 & 0.0 & 0.0 & 0.3 \\
\hline 13 & 0.5 & 0.0 & 0.2 & 1.0 & 1.5 & 0.2 & 0.5 & 0.5 & 0.0 & 0.0 & 0.0 & 0.0 & 0.1 & 0.5 & 0.0 \\
\hline 14 & 3.1 & 3.4 & 3.2 & 2.8 & 2.9 & 3.4 & 3.0 & 3.4 & 2.5 & 2.0 & 2.1 & 2.0 & 0.7 & 0.3 & 3.1 \\
\hline 15 & 1.5 & 3.2 & 4.1 & 2.1 & 4.5 & 4.3 & 1.1 & 3.1 & 0.0 & 0.0 & 0.4 & 0.0 & 0.8 & 0.0 & 0.0 \\
\hline 16 & 1.8 & 0.4 & 0.6 & 1.0 & 1.5 & 0.2 & 1.0 & 0.0 & 0.0 & 0.0 & 0.0 & 0.0 & 0.0 & 0.0 & 3.2 \\
\hline 17 & 0.5 & 0.1 & 0.1 & 0.2 & 0.3 & 0.0 & 0.0 & 0.0 & 0.0 & 0.0 & 0.0 & 0.0 & 0.0 & 0.0 & 0.7 \\
\hline 18 & 1.0 & 0.9 & 0.8 & 0.8 & 0.8 & 0.9 & 0.9 & 0.9 & 0.8 & 0.6 & 0.6 & 0.5 & 0.2 & 0.4 & 0.9 \\
\hline 19 & 0.4 & 0.2 & 0.4 & 0.2 & 0.7 & 0.8 & 0.0 & 0.0 & 0.0 & 0.0 & 0.0 & 0.6 & 0.0 & 0.0 & 0.0 \\
\hline 20 & 5.9 & 5.6 & 6.5 & 6.7 & 5.5 & 4.0 & 7.0 & 5.6 & 4.5 & 2.5 & 0.7 & 0.9 & 2.4 & 0.0 & 5.2 \\
\hline 21 & 0.6 & 0.6 & 0.1 & 0.0 & 0.1 & 0.4 & 0.3 & 1.0 & 0.0 & 0.0 & 0.0 & 0.0 & 0.0 & 0.4 & 0.0 \\
\hline 22 & 4.8 & 4.9 & 4.6 & 5.3 & 5.1 & 4.9 & 4.9 & 5.3 & 4.7 & 4.2 & 4.3 & 3.5 & 2.2 & 1.7 & 5.1 \\
\hline 23 & -0.2 & 0.0 & 0.0 & 0.0 & 0.0 & 0.0 & 0.0 & 0.0 & 0.0 & 0.0 & 0.0 & 0.0 & 0.0 & 0.0 & -0.1 \\
\hline 24 & -7.2 & -7.1 & -7.5 & -6.4 & -7.7 & -7.6 & -7.1 & -6.3 & -7.3 & -4.4 & -6.0 & -7.6 & -6.7 & -6.6 & -7.7 \\
\hline 25 & 0.0 & 0.0 & 0.0 & 0.0 & 0.0 & 0.0 & 0.0 & 0.0 & 0.0 & 0.0 & 0.0 & 0.0 & 0.0 & -3.1 & -6.5 \\
\hline
\end{tabular}

Note: $\mathrm{N}=$ Number of personal preference factors (Table 1, Column 1)

Source: Gyenizse 2014

the lack of large living spaces and privately owned gardens. Peculiarly, concrete apartments reached relatively high scores in all other personal preference factor, but they scored extremely low in their general physical conditions. Due to their local development planners, the blockhouse districts are easily accessible by public transportation (personal preference factors 6 to 10, see numbers $\leq 0$ in Table 4), they are usually well equipped with general public (personal preference factors 11 to 14), commercial and catering services (personal preference factors 15 to 19). Their general liveability assessment values are further increased by the proximity and accessibility of green areas, park and recreational facilities. Non-preferred factors only include air and noise pollution due to the main transportation routes through these districts (personal preference factors 23 to 25). 
The second type of low-score areas comprises family house districts (column 9 to 15). Districts of this type are not part of the conventional suburbanisation process. These districts include former rural areas which were administratively attached to the central settlement, like Kiskundorozsma in the case of Szeged, creating a local source of various urban development problems. Here, former hobby gardens and second homes were transformed into low-prestige residential areas. Their residents are classified into multiple status groups, including people of low-income, or people who lost their primary properties in the highly urbanised part of Szeged (Boros 2009). These areas, according to their personal preference factor qualities, were scored low in many aspects of our liveability assessment survey, including public transportation and proximity of educational, cultural or commercial facilities. Additional problems were also discovered when the general physical condition of the properties were assessed. This complex negative overview is exacerbated by the high concentration of low-income residents of marginal status that also markedly influence the subjective evaluation of these districts.

Here we identify a peculiar dual image: the unexpectedly low scores of the blockhouse districts, while, simultaneously, the family house districts are further deteriorated by their contra-selected population. Our findings corroborate the results and maps by former similar studies, where personal preference factors were generated by the liveability assessment of various subjective (relative to other status categories of the population) and objective (derived from social status) factors (Boros 2008). Boros (2008) points out that the population of the blockhouse districts underestimate their own social status compared to their financial conditions. This approach predominantly roots in the fact that concrete blockhouse apartments became the symbol of the socialist era, and the general image of apartments of these types are profoundly negative, which impacts their market price and initiate the segregation spiral being a typical social phenomena in certain post-socialist cities of Hungary.

In terms of the family house districts in Szeged, the existence of low-score areas corroborates the fact that in the Hungarian society, the possession of privately owned properties has an extremely highly ranked importance. To possess their own properties, most Hungarians are willing to be indebted in apparently inconvenient trade-offs, or decrease their general living standards.

How does the local urban development react to these challenges? To validate our model, we compared our results with the major concept of the City Development Plans and Integrated Urban Strategy of Szeged documents (ITS 2014). The ITS (2014) provided similar conclusions on the general conditions and living standards of 15 studied districts. The ITS also proposes the interior and exterior renewal of the blockhouses, the modernisation of the parks and the mitigation of pollution due to heavy traffic. The ITS also emphasizes the need for intense renewal of the Odessa blockhouse district (column 8 in Table 4). The second home districts of 
north and south Szeged are characterised with poor public utility supplies and infrastructure, insufficient accessibility and the low number of commercial and educational facilities. Despite this, there has been an increasing number of local population with low living standards here, resulting in pronounced segregation and social exclusion from the city.

Why does our GIS model supply more information than the existing urban development plans and documents? The benefit is the multifactor parameterisation, with which multiple attributes of a given area is determined. Spatial differences are identifiable even within a single apartment district, which may lead to different assessment levels and criteria system, thus provide better improvement and upgrade capabilities for the decision makers. Consequently, our model may provide substantial socio-economic planning algorithms and information for detailed action plans.

\section{Conclusion}

Social differentiation in the post-communist countries fundamentally transformed the spatial structure of large cities, with segregation and polarisation being the dominant social processes. The transformation markedly influenced the general physical conditions of the individual properties, residential districts and consequently their general liveability assessment and prices. Municipalities intended to solve these local social issues; however, strategic planning in Hungary possesses an insufficient instrumentation fleet, and is supported by undetailed background databases, analyses and basic research.

In the present study we introduced a new model, which is capable for the complex liveability evaluation and assessment of residential areas, calculating the personal preference values of a given district or area, based on the personal preference factors. Our model is also capable to spatially map each individual personal preference factor, and based on the model output, suggestions and recommendations can be made to solve district-level socio-economic problems.

Our model was tested and validated in the South Hungarian city of Szeged. For adequate validation, multiple personal preference factors were mapped and assessed based on their residential preferences or non-preferences in a given neighbourhood or residential district. The selected personal preference factors usually used in a daily or weekly basis, thus their presence or proximity have a primary importance when residents move or seek for a new home. With the help of a field questionnaire survey we assessed the impression of residents on blockhouse complexes, and then we mapped and vectorised 4,112 objects with field survey, maps and internet resources. By using various GIS procedures, we obtained two types of (expert range and residential range) assessment maps. Following 
spatial-statistical comparative methods, we used the obtained model to evaluate the liveability of residential districts based on the presence and proximity of personal preference factors. The map was weighted based on the input from the responders, but personal preference factor ranges were set by local experts and urban geographers.

We not only used the complex assessment map, but also used each individual map layers of the 25 personal preference factors. For the communal decision makers characteristic personal preference factors can be identified, but our model is also capable to derive information on the causative of extreme or mean values. With the aid of the model we identified the location of the lowest $3 \%$ score values. The most problematic areas of Szeged, in which immediate actions are indispensable, are located in the northern part of the city (housing estates). A second problematic area is found in the suburbs where miscellaneously developed areas and joined former villages create disturbed urbanisation and social segregation problems.

Our findings are in accordance with the Szeged's City Development Plans and Integrated Urban Strategy documents, in which similar spatial and social problems are presented as in the current study.

Our model nonetheless is capable for better spatial resolution than and strategic planning maps or documents currently available; consequently more exact spatial-structural identification can be achieved. Since our liveability assessment model is based on residential survey, the obtained model is relatively sophisticated and represents an objective and practical approach in urban personal preference factor assessment and planning. The model may contribute to the mitigation of the post-communist hectic socio-economic fluctuations, which lies between strategic planning theory and the current weaknesses of practical and methodological applications.

\section{References}

ACHILLAS, CH., VLACHOKOSTAS, CH., MOUSSIOPOULOS, N., BANIAS, G. (2011): Prioritize strategies to confort environmental deterioration in urban areas: Multicriteria assessment of public opinion and experts' view. Cities 28, 414-423.

ALJOUfIE, M., ZUIDGEEST, M., BRUSSEL, M., MAARSEVEEN, M. (2013): Spatial-temporal analysis of urban growth and transportation in Jeddah City, Saudi Arabia - Cities 31, 57.

ANDRUSZ, G., HARLOE, M., SZELÉNYI, I. (2008): Cities after socialism: urban and regional change and conflict in post-socialist societies, John Wiley \& Sons.

BAJMÓCY, P. (2009): Szeged város fejlődésének társadalomföldrajzi aspektusai a kezdetektől a 20. század közepéig. [The social geographic aspects of the development of Szeged from the beginning to the middle of the $20^{\text {th }}$ century] Földrajzi Közlemények, 133., i. 4., 447-452.

BLAZOVICH, L., ed. (2010): Szeged története 5. 1945-1990 [The history of Szeged 5. 1945-1990], http://www.sulinet.hu/oroksegtar/data/telepulesek_ertekei/szeged/szeged_tortenete_5/ index.htm. 
BOROS, L., PÁL, V. (2006): The effect of a hypermarket on the retail of Szeged. Geographica Timisiensis XV, 1, 79-86.

BOROS, L. (2008): Hol laknak a szegények? A depriváció térbelisége Szegeden. [Where do the poor live? The spatiality of deprivation in Szeged.] In: Szabó, V., Orosz, Z., Nagy, R., Fazekas, I. (eds.): IV. Magyar Földrajzi Konferencia, [IV. Hungarian Geographical Conference] Debrecen, 362-368.

BOROS, L. (2009): Szeged belső térfolyamatai az 1950-es évektől napjainkig. [The internal spatial processes of Szeged from the 1950s to these days] Földrajzi Közlemények 133, 4, 453-465.

CAVRIĆ, B., TOPLEK, S., ŠILJEG, A. (2008): Participatory measurements of sustainable urban development and quality of life in post-socialist Zadar, Croatia.

CASE, C., HAWTHORNE, T.L. (2013): Served or unserved? A site suitability analysis of social services in Atlanta, Georgia using Geographic Information Systems. Applied Geography 38, 96-106.

CZIGÁNY, S.Z., PIRKHOFFER, E., NAGYVÁRADI, L., SZEBÉNYI, A., VASS, P., GERESDI, I. (2010): Potential areas of flood impoundment in human environments, Bükkösd Valley, SW Hungary. Géomorphologie: Relief, Processus et Environnement, Revue du Grupe Francais de Geomorphologie, 2010/3, 301-310.

Description directory of the Hungarian Geodetic Reference, http://lazarus.elte.hu/gb/geodez/ geodind.htM.

EGEDY, T. (2000): Szegregáció és társadalmi kirekesztés a nagyvárosi lakótelepeken. [Segregation and social discrimination in the housing estates of the cities] Földrajzi Értesítő, 1-4., 93-108.

ELEKES, T. (2008): A földrajzi tényezők szerepe a településfejlődésben. [The role of the geographical impact on the settlements' develop] - Dialóg Campus Kiadó, Budapest-Pécs.

GAÁL, E., ed. (1991): Szeged története 3.1. RÉSZ, 1849-1919 [The history of Szeges 1. 1849-1919], http://www.sulinet.hu/oroksegtar/data/telepulesek_ertekei/szeged/szeged_tortenete_3_1/

GAUBE, V., REMESCH, A. (2013): Impact of urban planning on household's residential decisions: An agent-based simulation model for Vienna. Environmental Modelling \& Software 45, www.elsevier.com/locate/envsoft, 92-103.

Gazetteer of Hungary, ${ }^{\text {st }}$ January, 2013. Hungarian Central Statistical Office, http://www.ksh. hu/docs/hun/hnk/hnk_2013.pdf.

GBANIE, S.P., TENGBE, P.B., MOMOH, J.S., MEDO, J., TAMBA, V., KABBA, S. (2013): Modelling landfill location using Geographic Information Systems (GIS) and Multi-Criteria Decision Analysis (MCDA): Case study Bo, Southern Sierra Leone. Applied Geography, 36, 3-12.

GENTILE, M. (2003): Residential Segregation in a Medium-Sized Post-Soviet City: Ust'-Kamenogorsk, Kazakhstan. Tijdschrift voor Economische en Sociale Geografie, 94, 589-605.

GENTILE, M. (2004): Divided Post-Soviet Small Cities? Residential Segregation and Urban Form in Leninogorsk and Zyryanovsk, Kazakhstan. Geografiska Annaler: Series B, Human Geography, 86, 117-136.

GREKOUSIS, G., MANETOS, P., PHOTIS, Y.N. (2013): Modelling urban evolution using neural networks, fuzzy logic and GIS: The case of the Athens metropolitan area. Cities 30, 193-203.

GYENIZSE, P., NAGYVÁRADI, L., PIRKHOFFER, E., RONCZYK, L. (2007): Aesthetic assessment of a man-made landscape. Geografia física e dinamica quaternaria. Torino, Italy, 30, 2, 175-178.

GYENIZSE, P., ELEKES, T., NAGYVÁRADI, L. (2012): A hazai nagyvárosok beépített területének lakossági igények alapján való minősítése és annak problémái. [The evaluation of the built-up areas of Hungarian cities based on the residents' claims] In: Lóki, J. (ed.): Az 
elmélet és gyakorlat találkozása a térinformatikában. III. Térinformatikai Konferencia és Szakkiállítás, Debrecen, 143-150.

GYENIZSE, P. (2013): A hazai nagyvárosok lakott területének geoinformatikai minősítéséhez készített kérdőíves felmérés eredményeinek ismertetése. [The representation of the results of the survey which was done for the GIS evaluation of the inhabited areas of Hungarian cities]. Településföldrajzi Tanulmányok, 2013/1, 88-99.

GYENIZSE, P., ELEKES, T., BOGNÁR, Z., NÉMETH, S. (2013): GIS assessment of visual quality along the major thoroughfares of Pécs. Ecoterra. Journal of Environmental Research and Protection, 34., http://www.ecoterra-online.ro/files/1371284165.pdf, 13-19.

HIRT, S. (2013): Whatever happened to the (post) socialist city? Cities, 32, 29-38.

HIRT, S., STANILOV, K. (2007): The perils of post-socialist transformation: Residential development in Sofia. The Post-Socialist City. Springer.

HORVÁTH, Á., CZINKÁN, N., DANKÓ, S., FARKAS, M., GÖNDÖR, L., RÉVÉSZ, G., SOÓKITÓTH, G. (2013): A budapesti irodapiac térszerkezete. [Spatial structure of the Budapest office market]. Tér és Társadalom, 27, 1, 52-63.

KARANCSI, Z., HORNYÁK, S., HORVÁTH, G. (2012): Vizuális konfliktusok térképezése egy nagyvárosban . [The mapping of visual conflicts in a city] In: Győri, F. (ed.): A tudás szolgálatában: földrajzi tanulmányok Pál Ágnes tiszteletére. [In the service of knowledge: geographical studies in honour of Ágnes Pál] Szeged: Egyesület Közép-Európa Kutatására, 299-312.

KERTÉSZ, Á., MEZŐSI, G. (1991): The reduction of the dust pollution in Szeged (S-Hungary) with landuse optimalization based on GIS. In: Halker, M., Jaeschke, A (eds.): Computer Science for Environmental Protection. Heidelberg, Springer-Verlag, Berlin, New York, 504-514.

KISS, E. (2004): Spatial impacts of post-socialist industrial transformation in the major Hungarian cities. European Urban and Regional Studies, 11, 81-87.

KOTUS, J. (2006): Changes in the spatial structure of a large Polish city -The case of Poznań. Cities, 23, 364-381.

KOVÁCS, Z., DOUGLAS, M. (1996): A városépítés időzített bombája - avagy a magyar lakótelepszindróma társadalomföldrajzi megközelítésben. [The time-bomb of urban development - A social geographical approach of the Hungarian housing estate-syndrome] Földrajzi Értesítő, 1-2., 101-117.

KOVÁCS, Z. (1998): Ghettoization or gentrification? Post-socialist scenarios for Budapest. Netherlands Journal of Housing and the Built Environment, 13, 63-81.

KOVÁCS, Z. (1999): Cities from state-socialism to global capitalism: an introduction. GeoJournal, 49, 1-6.

KOVÁCS, Z. (2009): Social and economic transformation of historical neighbourhoods in Budapest. Tijdschrift voor Economische en Sociale Geografie, 100, 399-416.

KOVÁCS, Z., SZABÓ, S.Z., BURAI, P., SZABÓ, G. (2014): Tetőtípusok azonosítása hiperspektrális felvételek alapján. [The identification of types of roofs on the basis of hyperspectral images] In: Balázs, B. (ed.) Az elmélet és a gyakorlat találkozása a térinformatikában V.: Térinformatikai konferencia és szakkiállítás. [The meeting of theory and practice in geoinformatics V: Geoinformatic conference and exhibition] Debrecen, Magyarország, 2014.05.29-2014.05.31. Debrecen: Debreceni Egyetemi Kiadó, 181-188.

MARCIŃCZAK, S., GENTILE, M., STĘPNIAK, M. (2013): Paradoxes of (post) socialist segregation: Metropolitan sociospatial divisions under socialism and after in Poland. Urban Geography, 34, 327-352.

MARTINEZ, J.A. (2000): Evaluating housing needs with the use of GIS. Habitat International $24,501-515$. 
MEZŐ, B. (2013): Párhuzamos társadalmak - Szegregációs és Integrációs folyamatok Hajdúböszörményben. [Parallel societies - Segregation and Integration processes in Hajdúböszörmény]. University of Debrecen, PhD-Thesis, 53-54.

MYINT, S.W. (2008): An exploration of spatial dispersion, pattern, and association of socioeconomic functional units in an urban system. Applied Geography, 28, 168-188.

RAKONCZAI, J., UNGER, J., MUCSI, L., SZATMÁRI, J., TOBAK, Z., BOUDEWIJN, V.L., GÁL T., FIALA, K. (2009): A napfény városa naplemente után - Légi távérzékeléssel támogatott hősziget-térképezés Szegeden. [The city of sunlight after sunset - mapping of urban heat island using aerial remote sensing method in Szeged] Földrajzi Közlemények, 133, i. 4, 367-383.

RONCZYK, L., CZIGÁNY, S., BALATONYI, L., KRISTON, Á. (2012): Effects of excess urban runoff on wastewater flow in Pécs, Hungary, Riscuri si catastrofe 11, 2, 144-159.

RUOPPILA, S., KÄHRIK, A. (2003): Socio-economic residential differentiation in post-socialist Tallinn. Journal of Housing and the Built Environment, 18, 49-73.

RYBARCZYK, G., WU, C. (2010): Bicycle facility planning using GIS and multi-criteria decision analysis. Applied Geography 30, 282-293.

SAILER-FLIEGE, U. (1999): Characteristics of post-socialist urban transformation in East Central Europe. GeoJournal, 49, 7-16.

STANILOV, K. (2007a): The post-socialist city: urban form and space transformations in Central and Eastern Europe after socialism, Springer.

STANILOV, K. (2007b): Urban planning and the challenges of the post-socialist transformation. The Post-Socialist City. Springer.

SVORAY, T., BAR (KUTIEL), P., BANNET, T. (2005): Urban land-use allocation in a Mediterranean ecotone: Habitat Heterogeneity Model incorporated in a GIS using a multi-criteria mechanism. Landscape and Urban Planning 72, 337-351.

SÝKORA, L. (1999): Processes of socio-spatial differentiation in post-communist Prague. Housing Studies, 14, 679-701.

SÝKORA, L., BOUZAROVSKI, S. (2012): Multiple Transformations Conceptualising the Postcommunist Urban Transition. Urban Studies, 49, 43-60.

Szeged Megyei Jogú Város Településfejlesztési Koncepciója, RVI Magyarország Kft., 2014, http:// www.szegedvaros.hu/letoltesek/doc_download/3479-szeged-mjv-integralt-telepuelesfejlesztesi-koncepcioja-vegleges.html.

Szeged Megyei Jogú Város Integrált Településfejlesztési Stratégiája (2014-2020), RVI Magyarország Kft., 2014, http://www.szegedvaros.hu/letoltesek/doc_download/3480-szeged-mjvintegralt-telepuelesfejlesztesi-strategiaja-vegleges.html

SZÉKELY, J. (2008): Reasons of Local Housing Market Price Differences in Hungary. Hungarian Statistical Review, 86, 12. 174-188.

TÁNCZOS-SZABÓ, L., BRINDZA, A. (2014): Socio-Economic Problems of the HungarianSerbian Border Region as Reflected in Building Plot Prices. In: Efe, R., Ozturk, M. (eds): Environment and Ecology in the Mediterranean Region II. Cambridge Scholars Publishing, 147-166.

TÓTH, K., KESERÜ, I. (2001): A szegedi lakótelepi panellakások árainak területi különbségei. [The spatial differences of the prices of prefabricated houses in the housing estates of Szeged] In: Dormány G, Kovács F., Péti M., Rakonczai J. (eds.) A földrajz eredményei az új évezred küszöbén: Magyar Földrajzi Konferencia. [The results of Geography at the turn of the millennium: Hungarian Geographical Conference] Szegedi Tudományegyetem TTK Természeti Földrajzi Tanszék, 2001. Paper 1.

TSENKOVA, S. (2007): Reinventing strategic planning in post-socialist cities: Experiences from Sofia. European Planning Studies, 15, 295-317. 
ZHOU, Y., THILL, J.C., HUANG, Z. (2011): Design of a user-centric decision support tool for fixed-route bus travel planning. Applied Geography 31, 173-184.

\section{SHRNUTí}

\section{Vícefaktorový model ke klasifikaci městských obytných čtvrtí, sestavený podle názorů obyvatel}

Sociální diferenciace v postkomunistických zemích od základu proměnila prostorovou strukturu velkých měst, kde se staly dominantními společenskými procesy segregace a polarizace. Transformace podstatně poznamenala fyzické poměry jednotlivých objektů a obytných čtvrtí a posléze i to, jak bylo obecně hodnoceno tamější bydlení a jeho ceny. Obce měly v úmyslu řešit tyto místní sociální otázky, avšak strategické plánování v Mad'arsku trpí nedostatečnou paletou nástrojů a opírá se o podkladové databáze, analýzy a základní výzkum bez patřičné podrobnosti.

V předkládané studii jsme představili nový model, s nímž lze komplexně vyhodnotit vlastnosti obytných objektů a čtvrtí. Také lze vypočítat hodnoty osobních preferencí u konkrétního obvodu nebo čtvrti. To vše vychází z faktorů osobní preference. Náš model též umí prostorově zmapovat každý faktor osobní preference a na základě modelového výstupu pak lze formulovat návrhy a doporučení, aby byly řešeny socioekonomické problémy na úrovni čtvrtí.

Náš model byl vyzkoušen a ověřen v jihomad'arském městě Segedínu. K náležitému ověření bylo zmapováno množství faktorů osobní preference a pak vyhodnoceno na základě preferencí bydlení v dané čtvrti či obvodu, nebo naopak nechuti k němu. Vybrané faktory osobní preference se obvykle použily na denní nebo týdenní bázi, a tak jejich přítomnost nebo blízkost mají prvořadý význam, když se obyvatelé stěhují nebo uvažují o novém bydlišti. Metodou terénního dotazníkového výzkumu jsme hodnotili dojem obyvatel ze sídlišt a potom jsme pomocí terénního průzkumu, různých map a internetových zdrojů zmapovali a opatřili vektorem 4112 objektů. Při použití různých postupů ze sféry GIS jsme získali dva typy hodnotících map (odborné mapy rozsahu a mapy obytného rozsahu). Díky prostorově statistickým srovnávacím metodám jsme získaný model použili k vyhodnocení, do jaké míry jsou obytné čtvrti přitažlivé z hlediska bydlení, přičemž jsme vycházeli z přítomnosti a blízkosti faktorů osobní preference. Mapa byla sestavena na základě výpovědí respondentů, ale rozsah faktorů osobní preference určili místní odborníci a městští geografové.

Použili jsme nejen mapu celkového vyhodnocení, ale také všechny jednotlivé mapové vrstvy u 25 faktorů osobní preference. Lze určit charakteristické faktory osobní preference pro místní rozhodovací činitele. Navíc je náš model schopen odvodit informace o kauzálních faktorech extrémních či průměrných hodnot. S pomocí modelu jsme určili umístění hodnot z nejnižšího pásma tří procent. Nejproblematičtější území v Segedínu, u nichž je naprosto nezbytný okamžitý zásah, se nacházejí v severní části města (sídliště). Druhá problematická oblast se rozkládá na předměstí, kde neuspořádaně vzniklé čtvrti a připojené bývalé vesnice plodí problémy v podobě chaotické urbanizace a sociální segregace.

Naše zjištění jsou v souladu s podklady Rozvojových plánů a Integrované městské strategie města Segedínu, kde jsou podobné prostorové a sociální problémy představeny v jedné současné studii.

Náš model nicméně dovede lepší prostorové rozlišení než mapy a podklady strategického plánování dostupné v současnosti, takže lze dosáhnout přesnějšího prostorového a strukturálního 
určení. Náš model ocenění v oblasti bydlení vychází z průzkumu v obytných čtvrtích, a tak je získaný model na relativně vysoké úrovni a nabízí objektivní a praktický př́stup k hodnocení a plánování městských faktorů osobní preference. Tento model může přispět ke zmírnění hektických výkyvů v postkomunistické společnosti a ekonomice. Může se uplatnit u teorie strategického plánování a pomáhat překonat současné slabiny praktických a metodologických aplikací.

Obr. 1 Geografická poloha města Segedín. Zdroj: Gyenizse 2014

Obr. 2 Městské čtvrti a krajina města Segedín. A - obytné čtvrti, B - průmyslové a rekreační oblasti nezahrnuté ve studii, C - řeky a jezera, D - silnice, 1 - historické město (centrum), 2 - vnitřní část města, 37-43 - zeleň v obytných čtvrtích. Zdroj: Gyenizse 2014.

Obr. 3 Základním principem modelu je závislost hodnoty vlastností na vzdálenosti k nejbližší službě a na fyzické vlastnosti budov. Tento princip byl vizualizován a modelován pomocí rastrových vrstev v GIS (bližší popis je uveden v textu). Zdroj: Gyenizse 2015.

Obr. 4 Vývojový diagram postupu zpracování. Zdroj: Gyenizse 2014.

Obr. 5 Zobrazení digitalizovaných bodů, linií a polygonů. Zdroj: Gyenizse 2014.

Obr. 6 Typy rezidenčních nemovitostí ve městě Segedín (A) a průměrná cena domu podle čtvrti města a typu bytových domů (B). V legendě: 1 - rodinný dům, 2 - řadový dům, 3 - cihlový dům, 4 - panelový dům. Zdroj: Gyenizse 2014.

Obr. 7 Po shrnutí všech 25 faktorů byly vyhotoveny hodnotící mapy obytných čtvrtí s vyznačením limitních vzdáleností podle obyvatel (A) a limitních vzdáleností podle odborníků (B). Zdroj: Gyenizse 2014.

Obr. 8 Mapa města s průměrnými cenami v obytných čtvrtích města dle obyvatel (A), odborníků (B) a průměrných cen (C). Zdroj: Gyenizse, Bognár 2014.

Obr. 9 Umístění obytných domů s nejnižším počtem bodů (3\% nejnižších hodnot). Zdroj: Gyenizse 2014.

\section{ACKNOWLEDGEMENTS}

This paper was supported by the János Bolyai Research Scholarship of the Hungarian Academy of Sciences. 